\title{
أسلوب الترديد في القرآن الكريم
}

\section{The paronomastic repetition method in the Holy Qur'an}

تاريخ الاستلام : 2017/04/17 ؛ تاريخ القبول : 2018/07/10
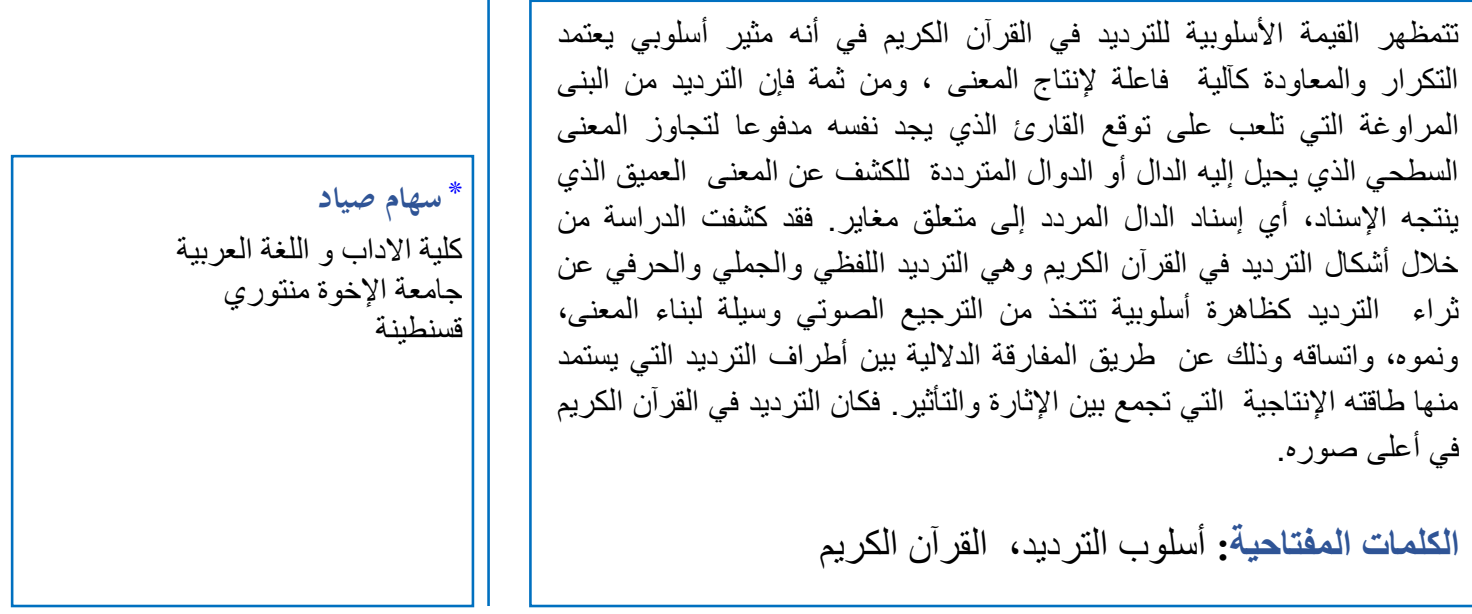

\section{Abstract}

The stylistic value of the paronomastic repetition in the Holy Qur'an appears in the fact that it is a method that depends on repetition as an effective mechanism for meaning production.

Hence, the paronomastic repetition is considered as an allusive structure that relays on the reader prediction who forcely transcends the superficial meaning that signifiers refer to, to reveal the deep meaning produced by the repeated signifier to a different concept.

The study revealed through the paronomastic repetition in the Holy Qur'an forms that are verbal, sentence and literal repetitions, it revealed the richness of repetition as a stylistic phenomen on that makes from the voice reverberation as a means to build meaning, its evolution and cohesion via the semantics diversity in repetition for which the productive energy is used and that gathers excitement and influence. So, the paronomastic repetition in the Holy Qur'an was in its best forms.

Keywords: Holy Qur'an, the paronomastic repetition, Forms of repetition

\section{Résumé}

La valeur stylistique de la réitération dans le Saint Coran se manifeste dans le fait qu'elle est un stimulant stylistique qui s'appuie sur la répétition en tant que mécanisme actif pour produire du sens. Donc, la réitération est l'une des structures astucieuses qui trompe l'attente du lecteur. Ce dernier se trouve obligé de surpasser le sens superficiel auquel renvoie(nt) le/les signifiant(s) répété(s) pour dévoiler le sens profond produit par la prédication, c'est-à-dire attribuer le signifiant réitéré à un autre prédicat. L'étude a révélé la richesse de la réitération, à partir de ses formes dans le Saint Coran (réitération d'un mot, d'une phrase, d'une particule), en tant que phénomène stylistique ayant l'allitération sonore comme outil pour la production, la progression et la cohérence du sens par le biais du paradoxe sémantique existant entre les différentes parties de la réitération et à partir desquelles elle puise sa capacité de production qui rassemble le suspense et l'influence. C'est ainsi qu'on peut constater que les formes de la réitération sont le plus apparent dans le Saint Coran.

Mots clés: le Saint Coran, la réitération, les formes de la réitération

* Corresponding author, e-mail sihamsiade@gmail.com 


\section{مقدمة}

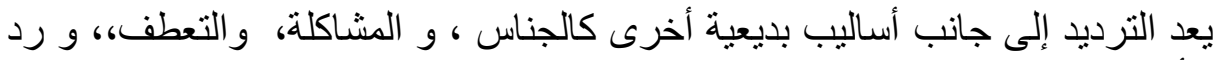

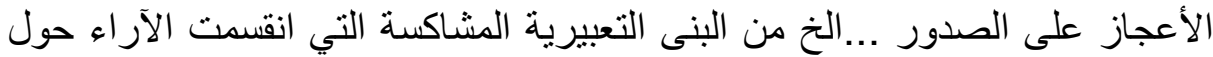

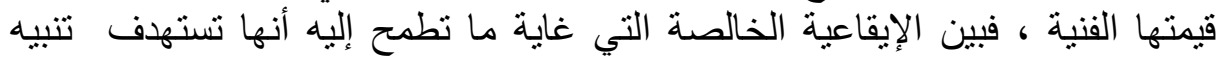

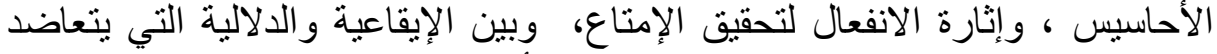

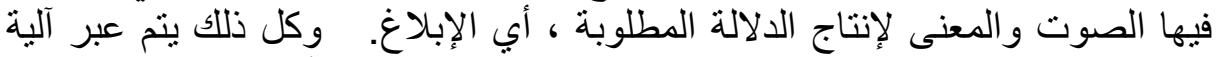

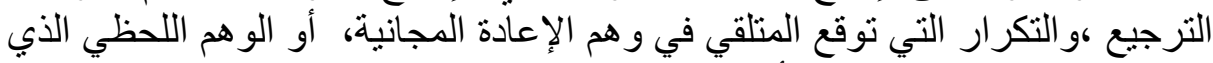

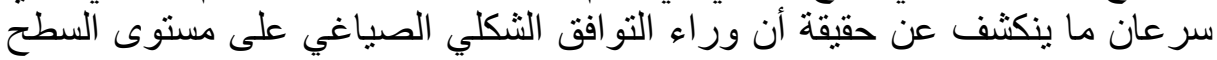

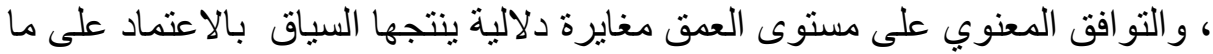

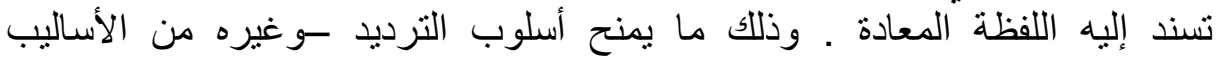

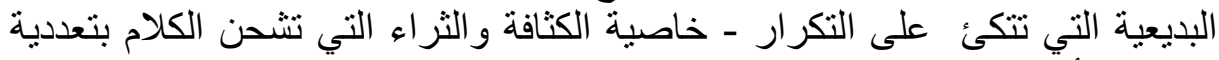

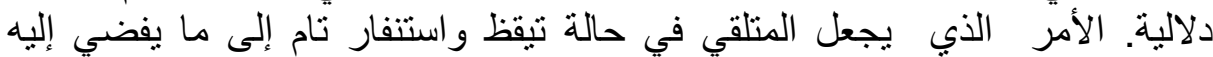

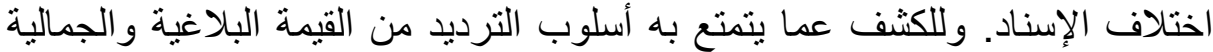

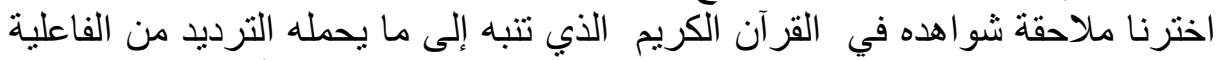

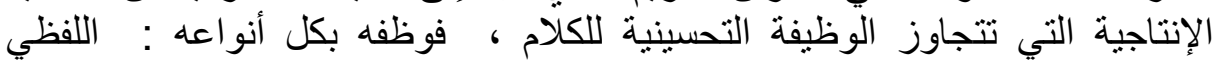
و الجملي والحرفي ـ وقد اعنمدنا في ذلك على المنهج الأسلوبي باعتباره أنجع وسيلة التيلة

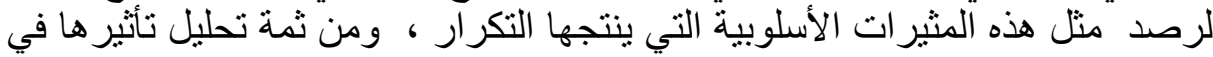

الكلام للوقوف على جماليتها.

تستمد ظاهرة الترديد قيمتها الأسلوبية من احتفائها بالصوت و والمعنى في الوقت نفسه .

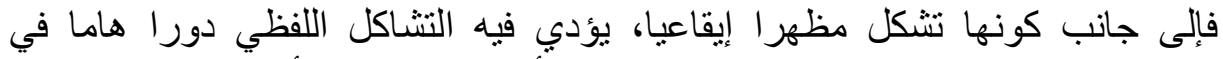

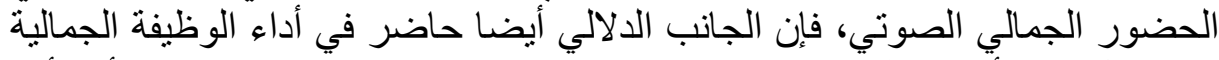

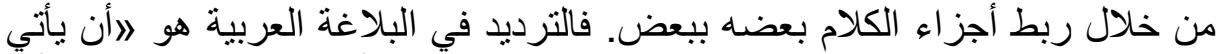

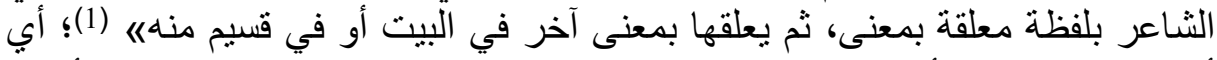

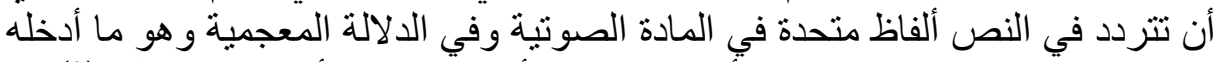

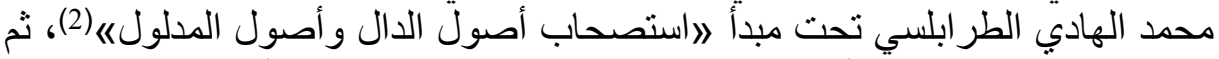

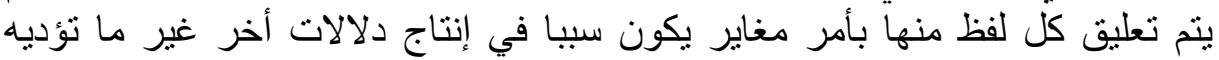

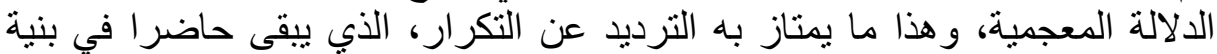

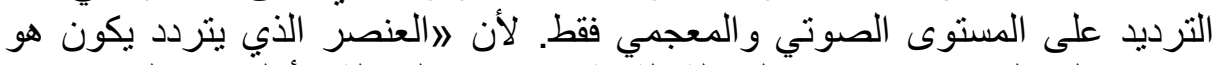

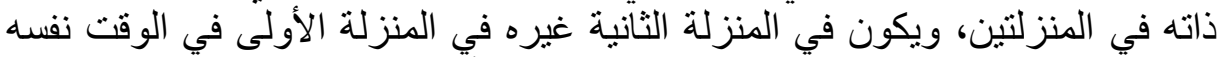

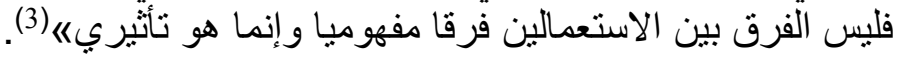

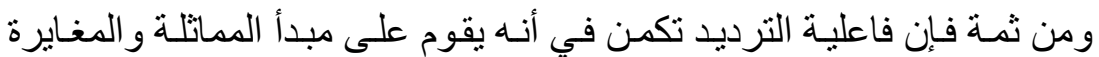

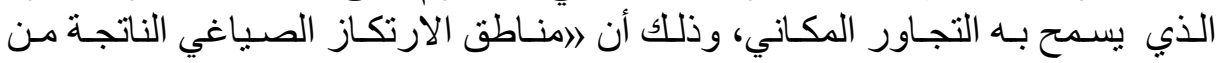

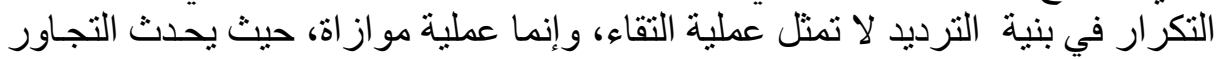

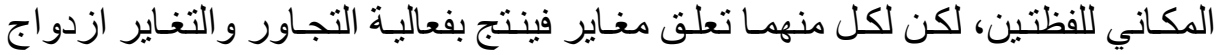

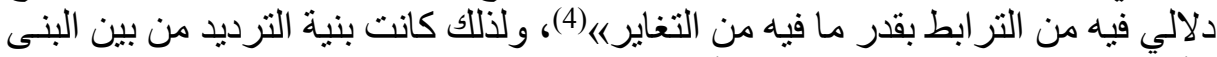

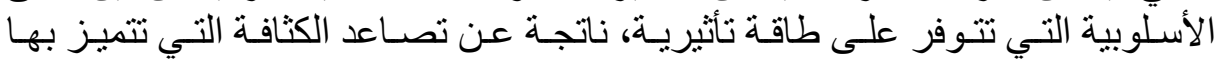

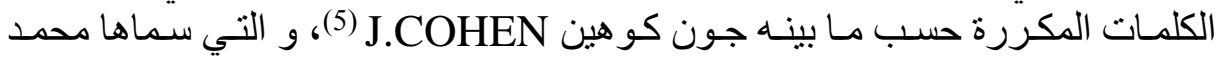

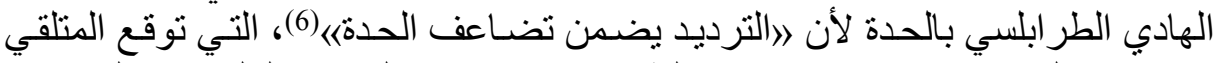

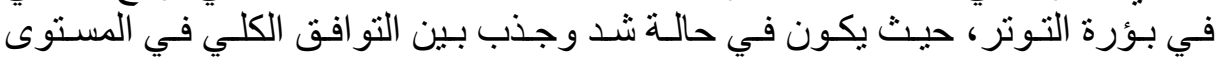

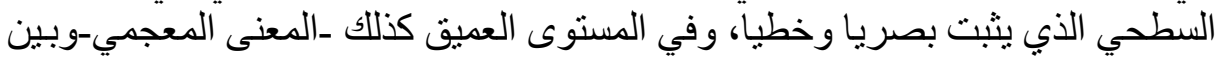
الاختلاف الذي يسبيه اختلاف الإسناد. وفي ملاحقة لظاهرة الترديد في القرآن آلكريم، الكين 
وجدنا أن الترديد يتمظهر فيها بأنو اعه الثناثنة وهي: الترديد اللفظي، و الترديد الجملي، و الترديد الحرفي. ومن الأمثلة:

1.2 -الترديد اللفظي: 1. 1.

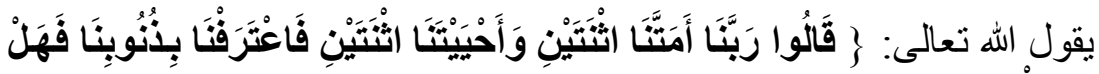

إلَّلَ خُرُوجِ مِنْ سَبِيلِِ

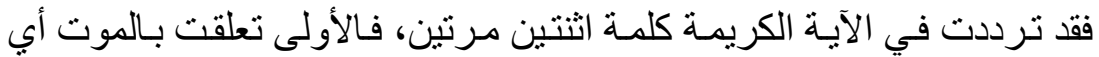

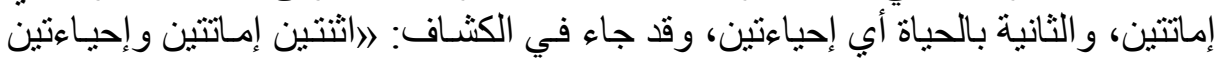

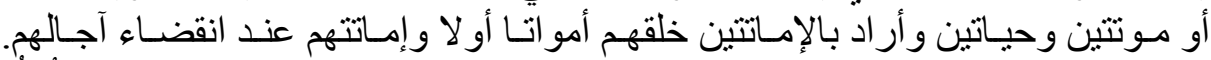

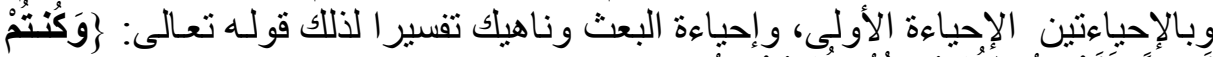

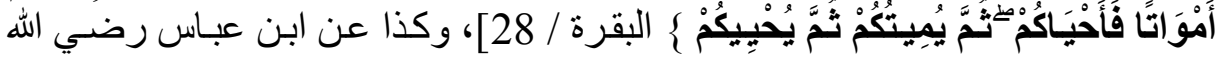

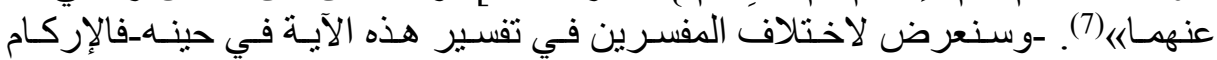

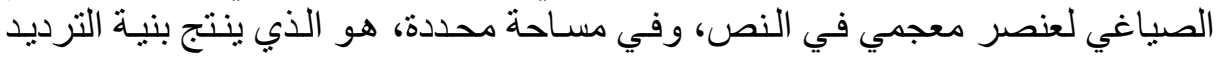

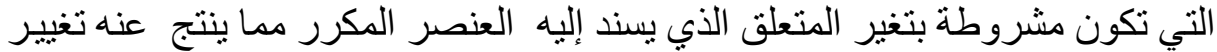

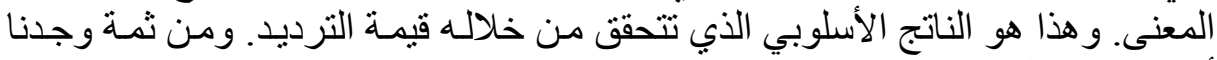

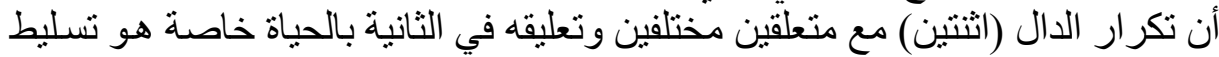

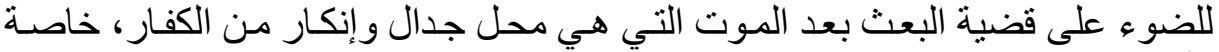

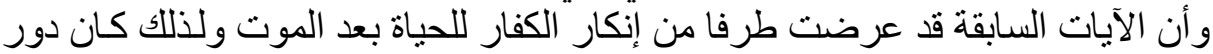

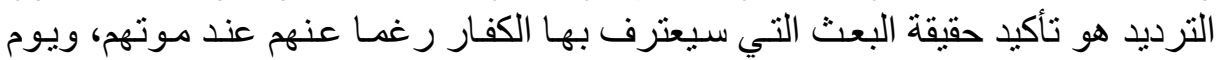
القيامة كما تبين ذلك الآية.

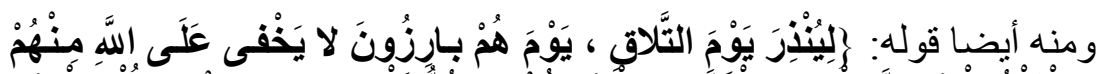

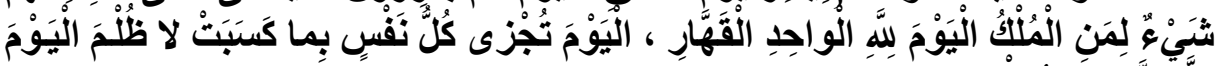

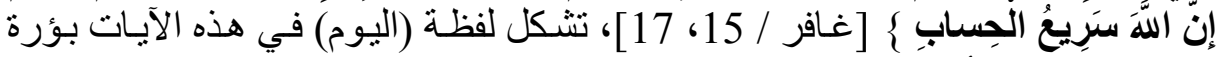

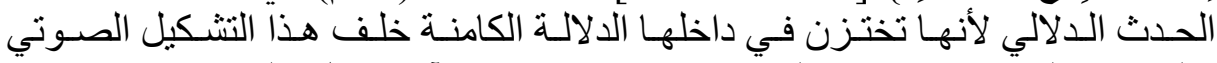

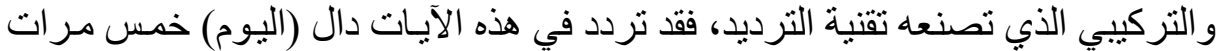

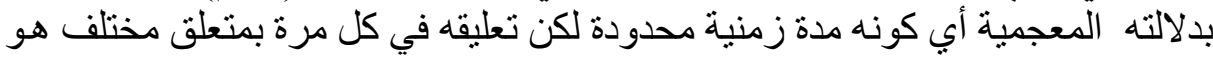

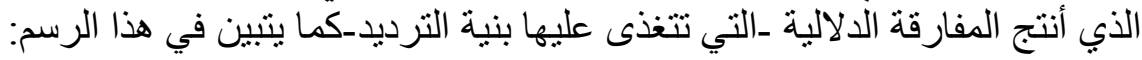

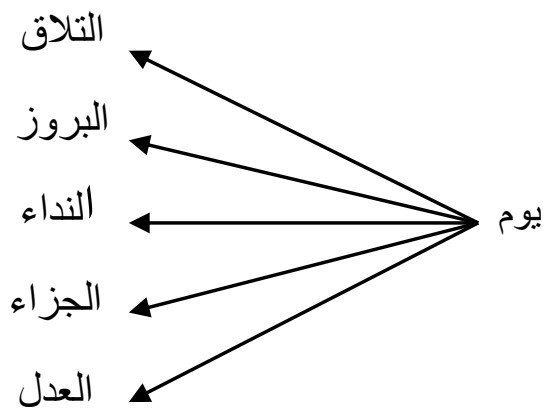

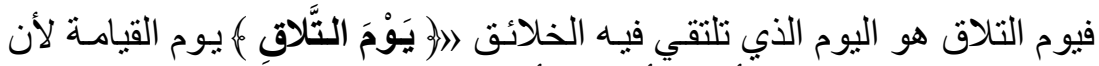

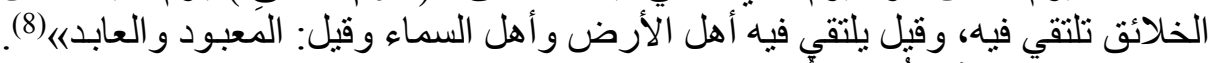

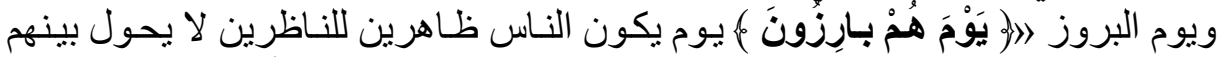

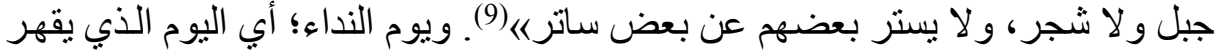




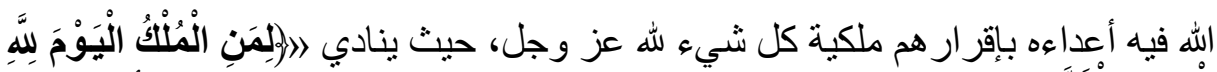

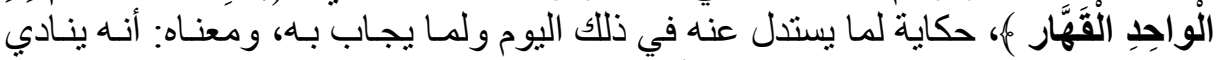

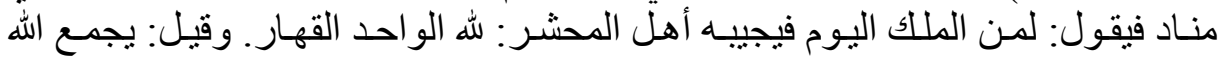

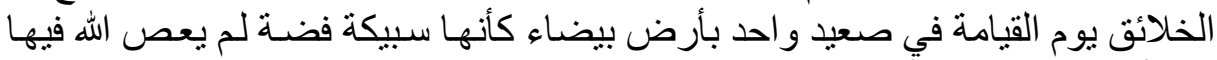

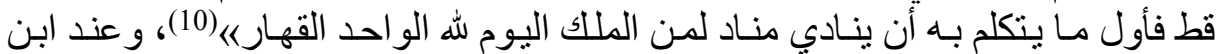

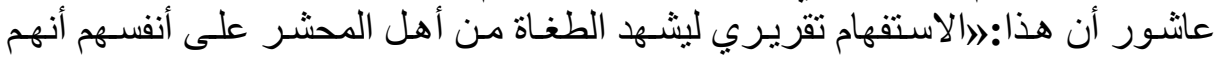

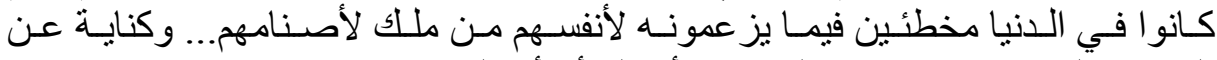

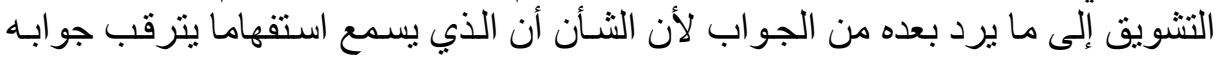

فيتمكن من نفسه الجواب عند سماعه فضل الف تمكنه(11).

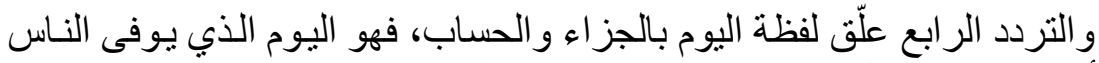

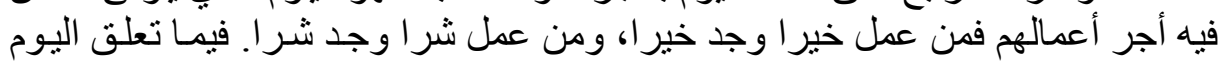

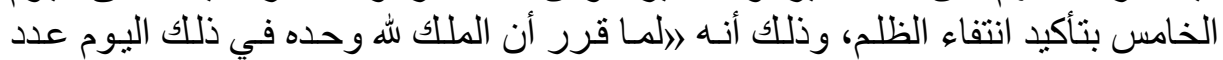

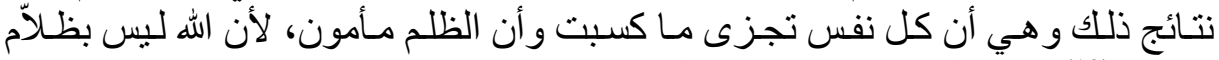

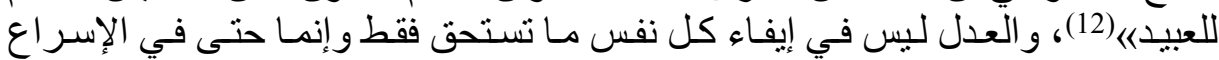

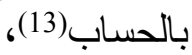

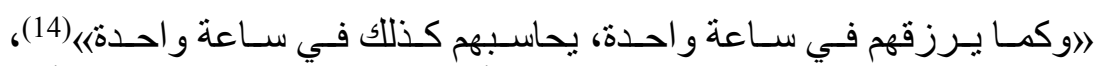

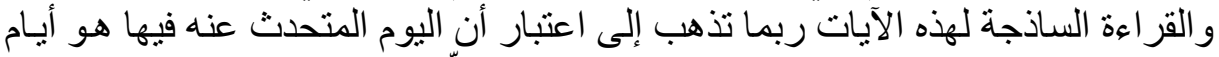

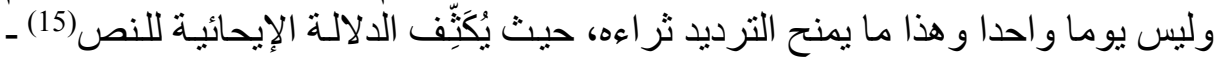
التي هي نتاج التكر ار - مذأ.

فالترديد يكسب النص اتساعا و انفتاحسا على دلالات متعددة تنسل كلهـ تلها من دال

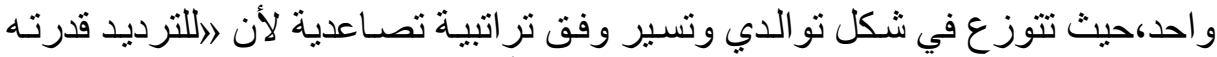

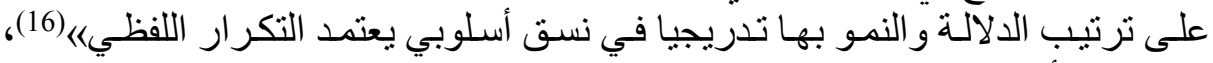

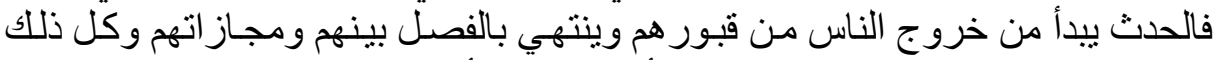

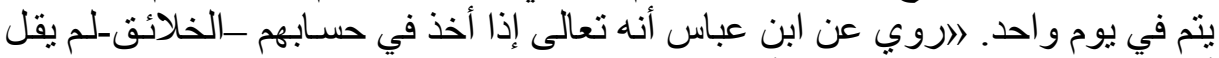
أهل الجنة إلا في الجنة ولم يقل أهل النار إلا في الناري(17).

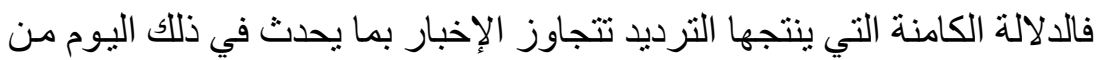

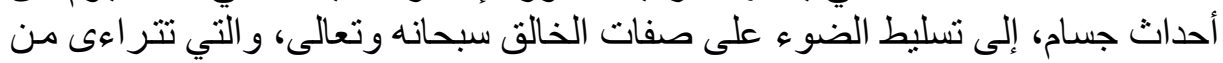

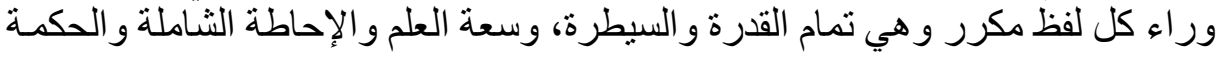

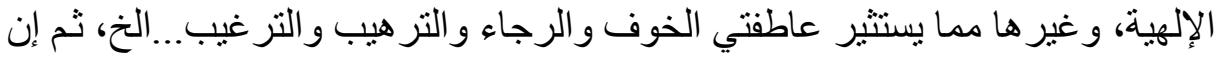

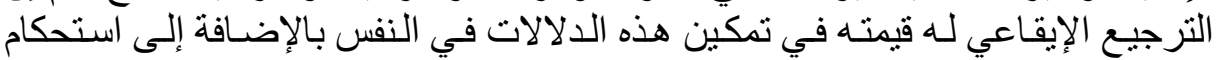
النظم وتقوية الدلالة(18).

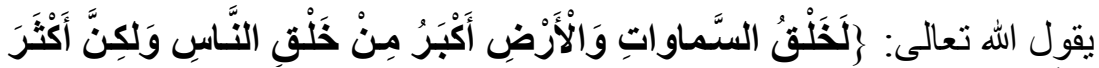

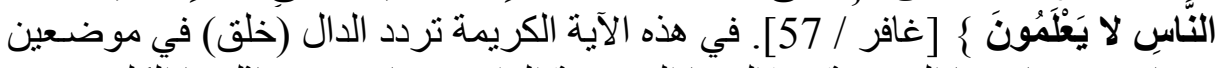

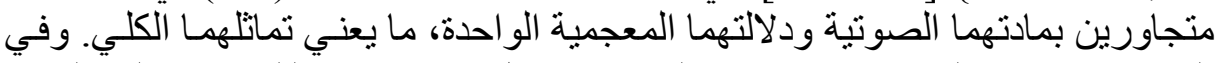

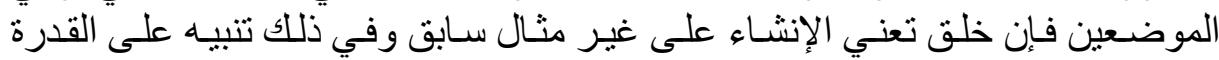

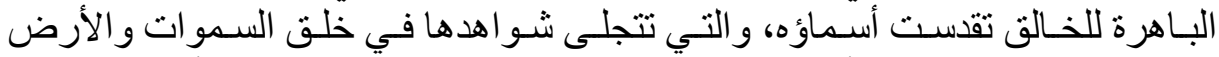

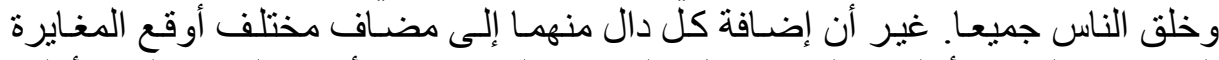

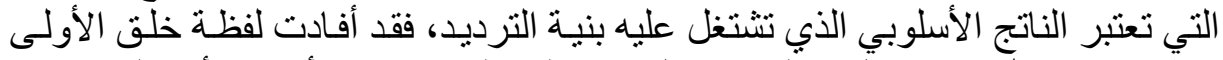

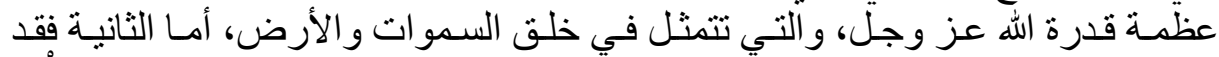

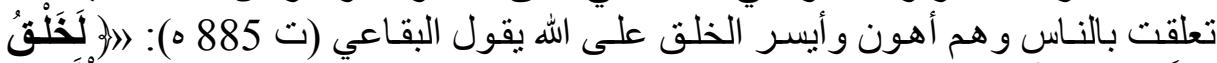

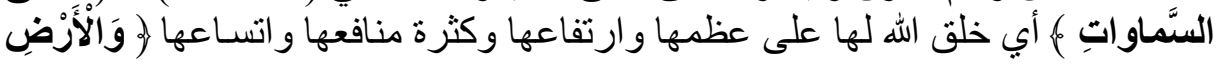




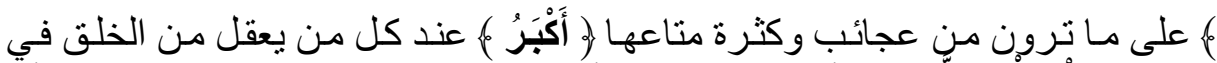

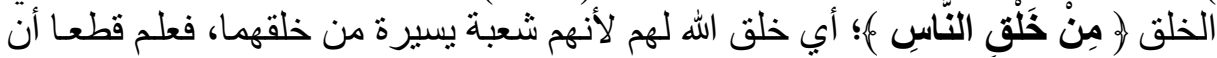

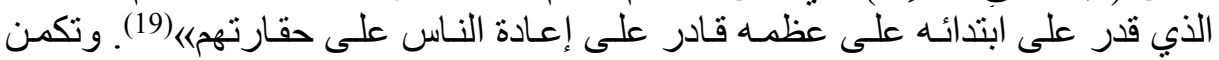

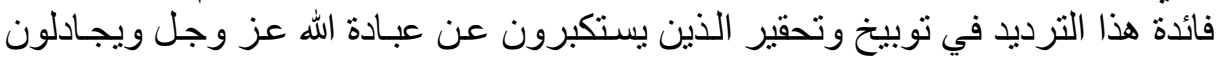

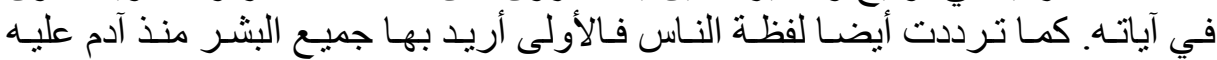

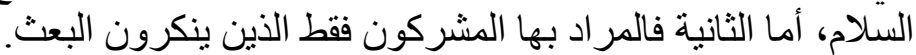

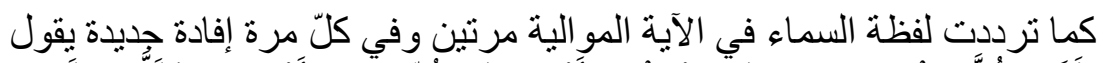

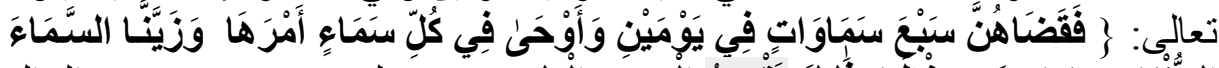

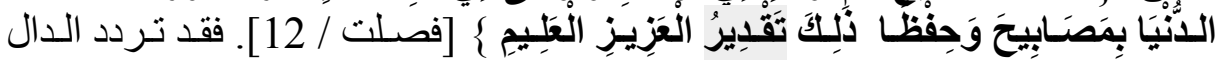

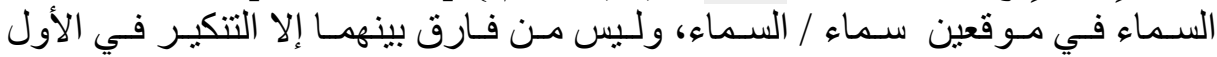

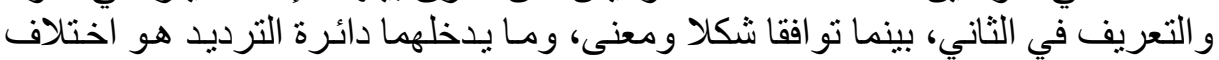

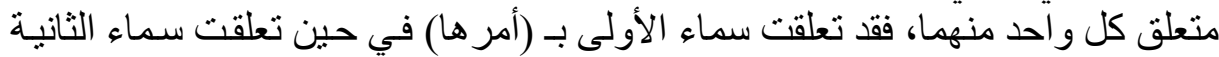

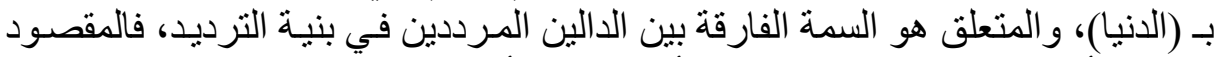

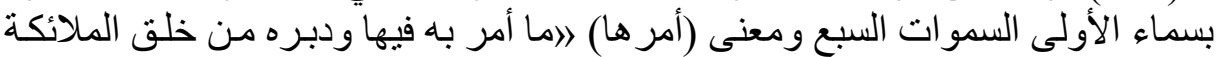

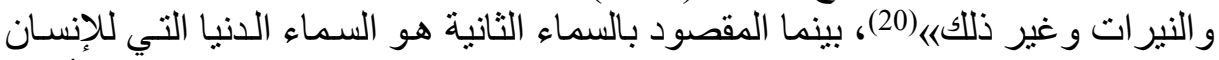

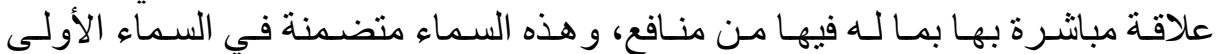

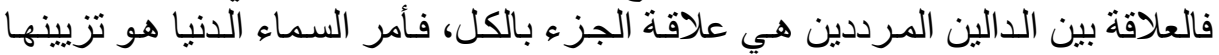

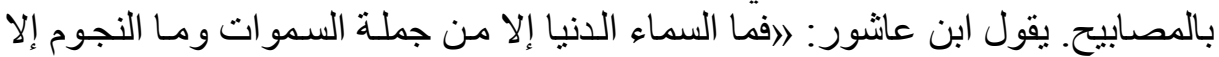

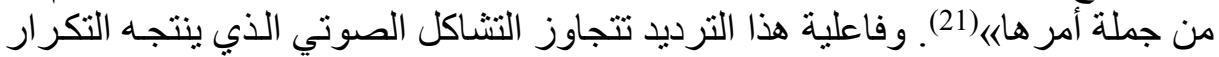

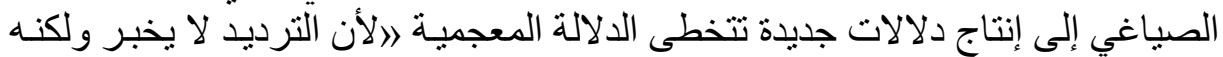

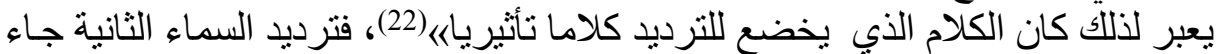

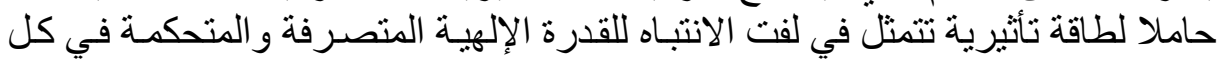

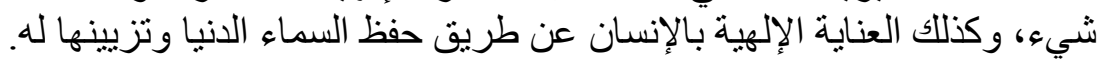

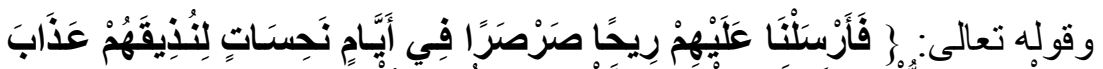

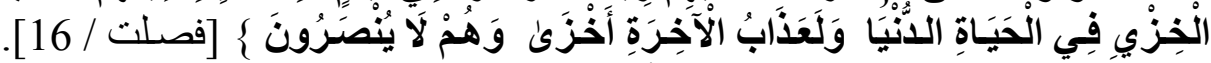

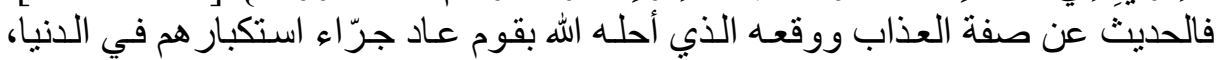

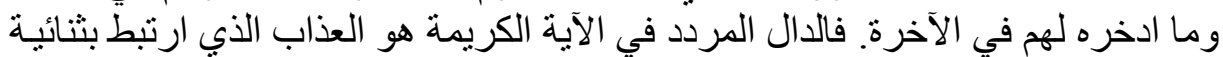

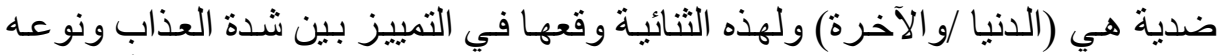

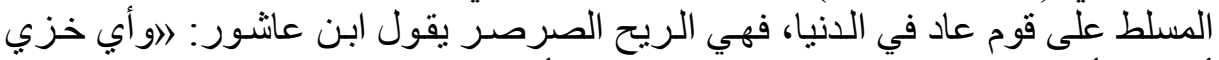

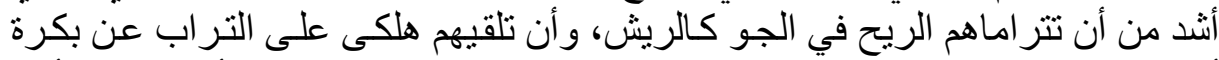

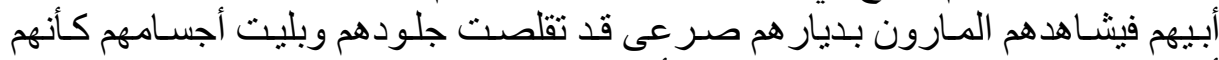
أعجاز نخل خاويةها(23)، وهو العذاب الأشد إخزاء و إذلالا في الآخرة. وفي هذا الترديد

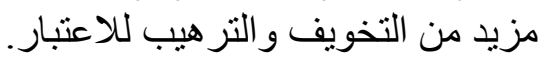

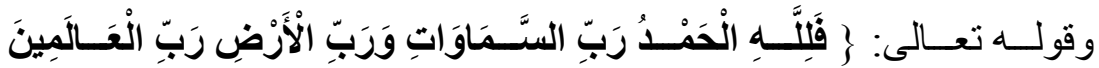

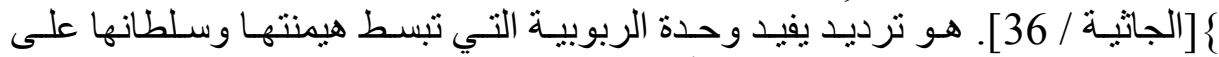

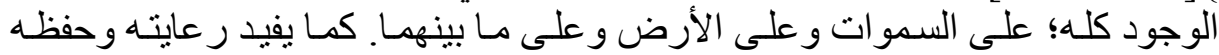

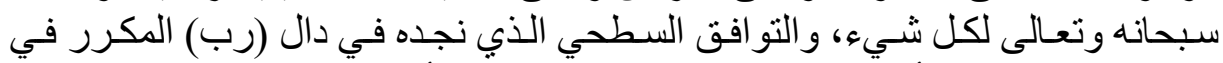

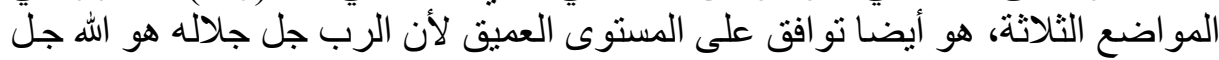

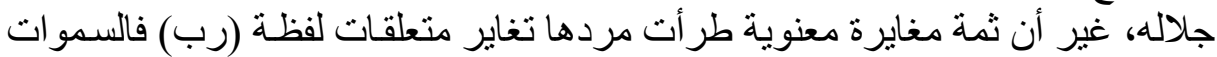

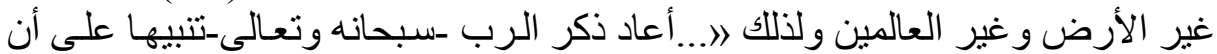

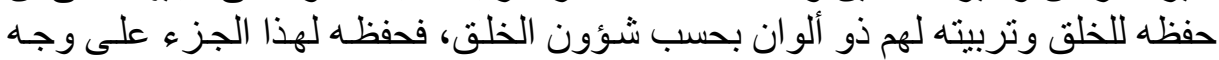

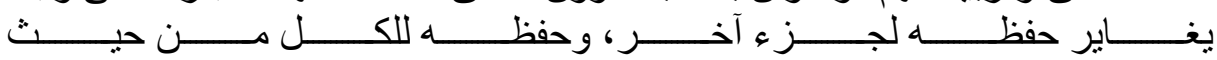
هو كل على وجه يغاير حفظه لكل جزء على حده، مـع أن الكل بالنسبة إلى تمـام القدرة 
على حد سـواء《|24). وقـال الآلوسـي (ت 1270 ه) إن: (افي تكريـر لفظ الرب تأكيد و إيذان بأن ربو بيته تعالى لكل بطريق الأصالة)(25).

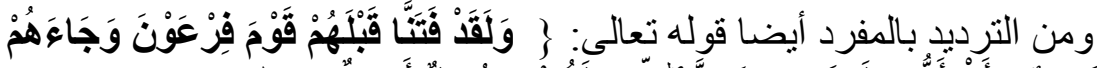

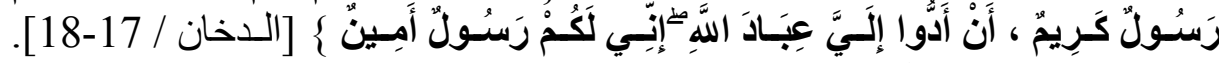

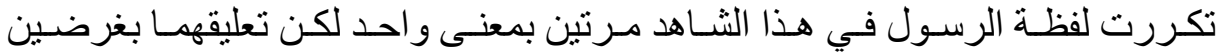

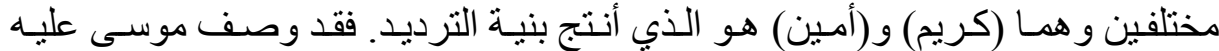

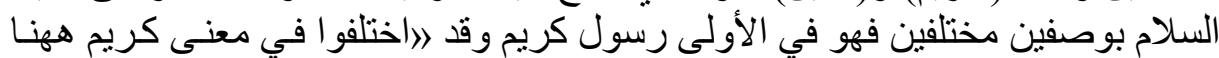

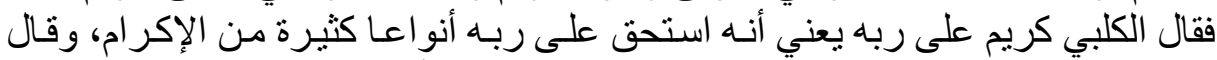

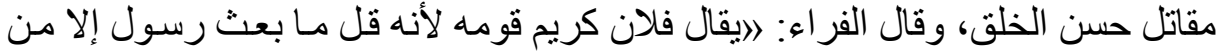

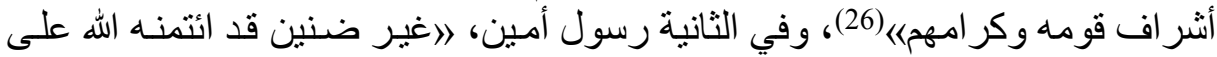

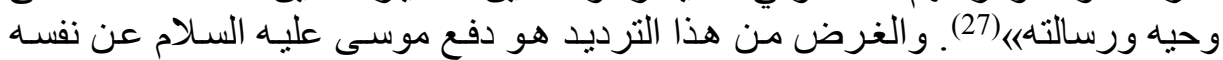

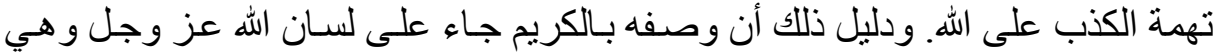

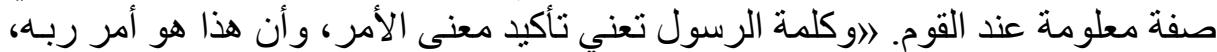

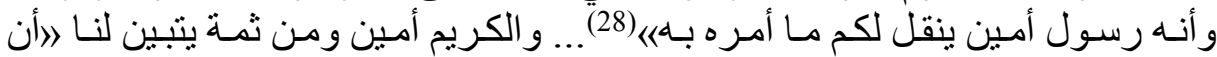

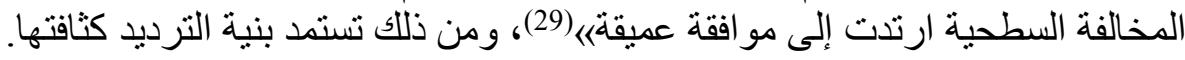

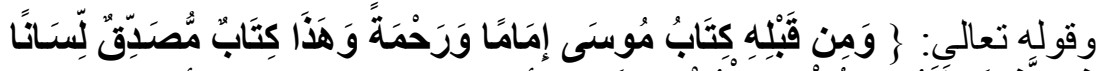

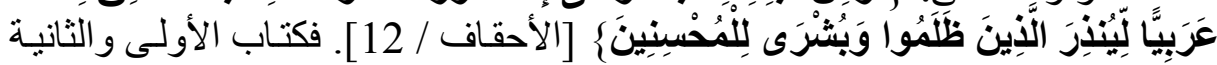

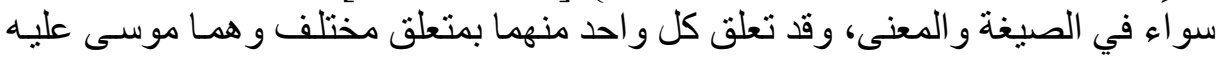

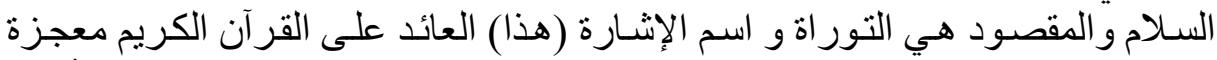

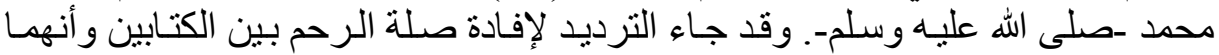

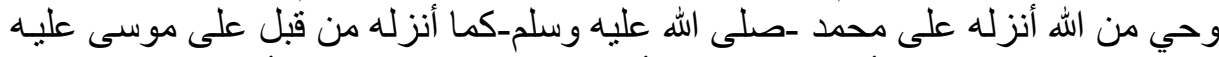

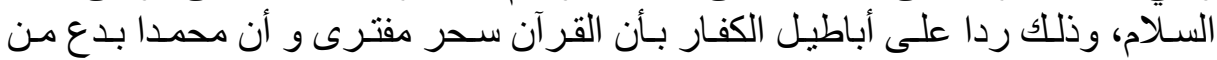

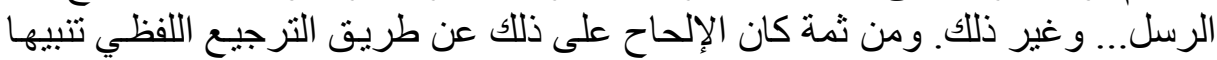

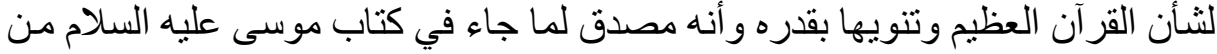

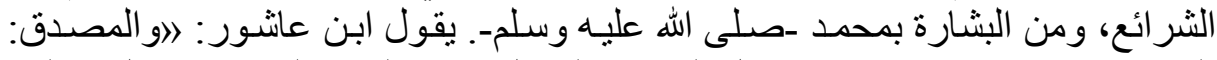

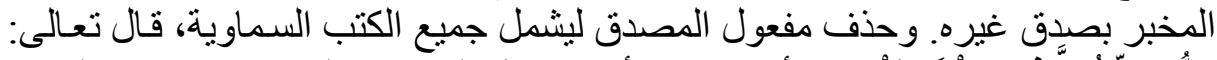

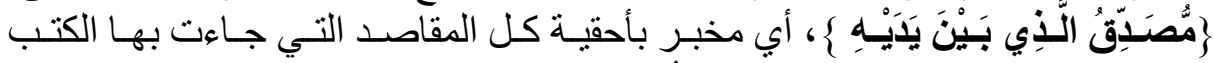

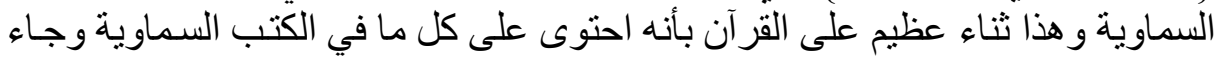
مغنيا عنها ومبينا لما فيهاهي(30).

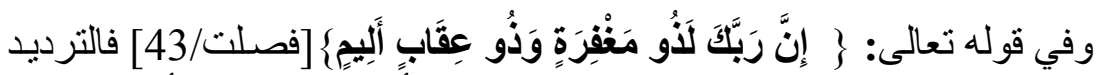

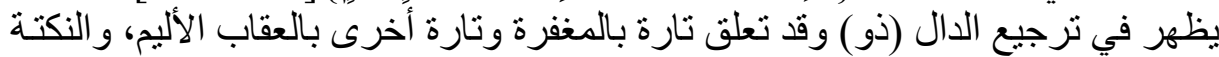

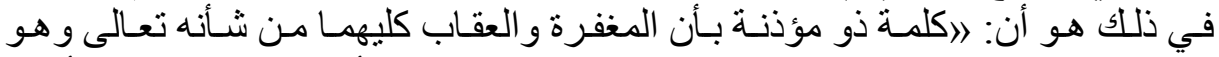

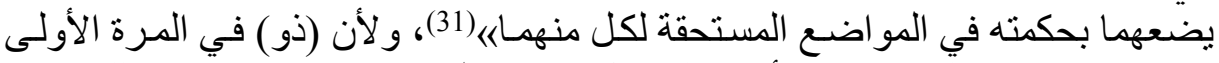

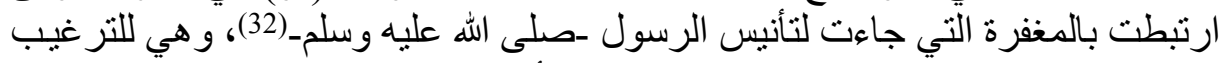

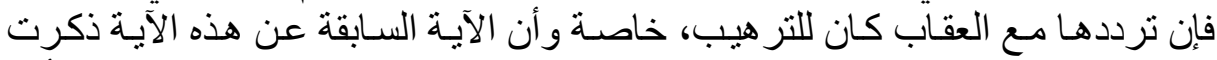

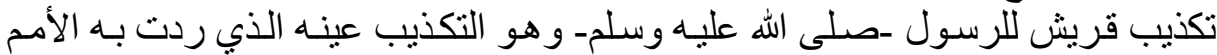

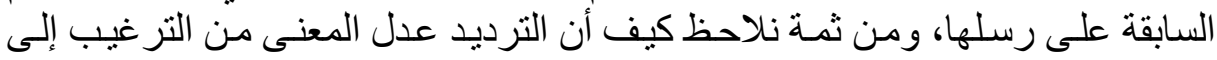

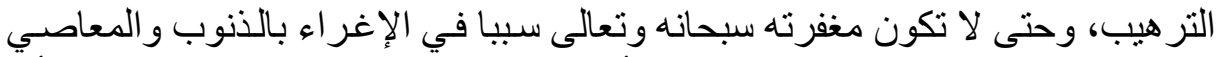

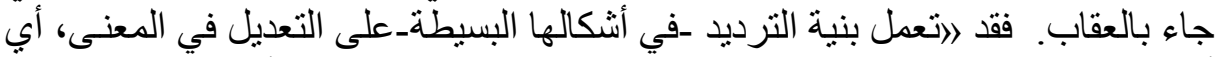

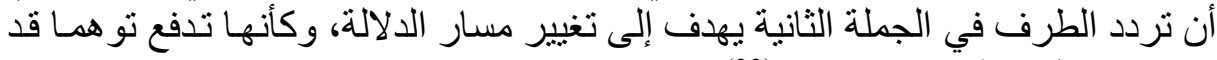

يكون، وتحل محله حقيقة كائنةر (33). 


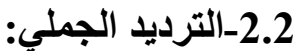

وقد تمتـد مسـاحة الترديد متخطيـة حدود الكلمـة المفردة فعـلا كانت أو اسـما

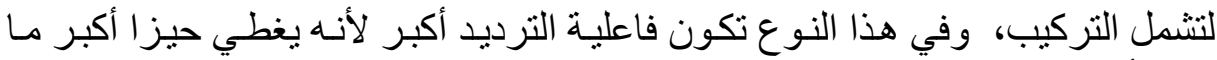
يسهم أكثر في سبك النص وفي هذات التحامه.

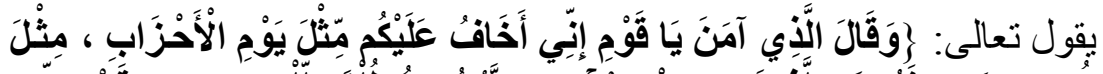

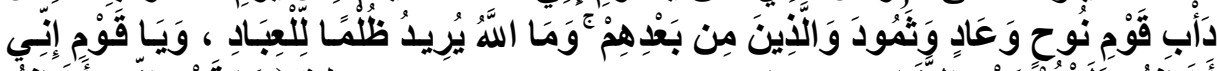

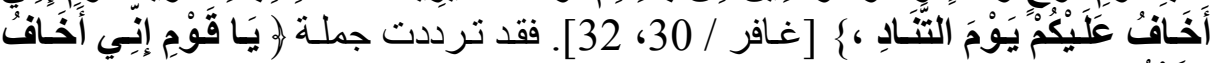

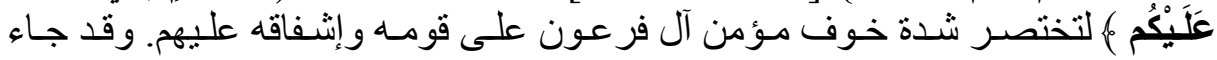

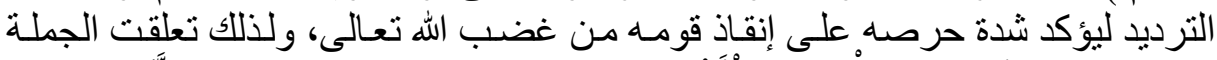

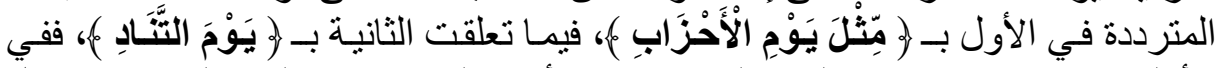

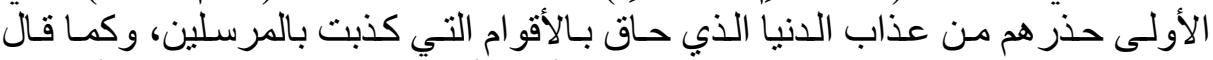

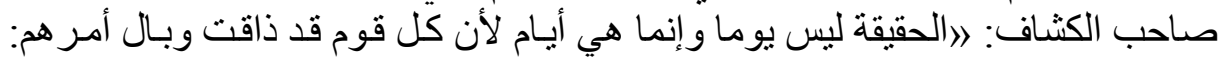

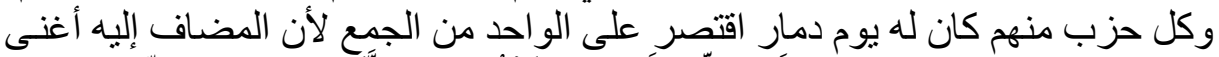

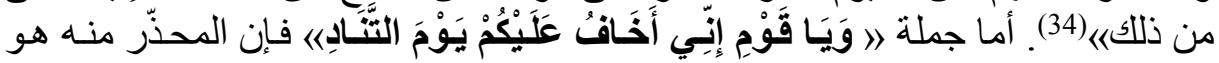
عذاب يوم القيامة.

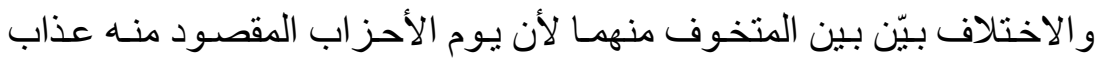

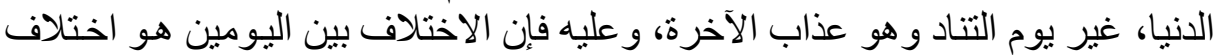

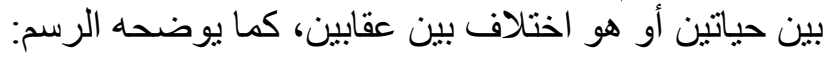

يوم الأحزاب (الحياة الدنبا) - ـ عذاب الاستئصسال (الانقضاء)

يوم التناد (الحياة الآخرة ) - ـ عذاب جهنم (الاستمر ارية)

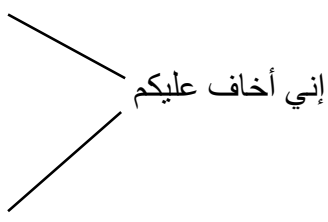

و على الر غم من هذا التضاد بين المتعلقين بالجملة المرددة \ه إِتِّي أَخَافُ عَلَيْكُم

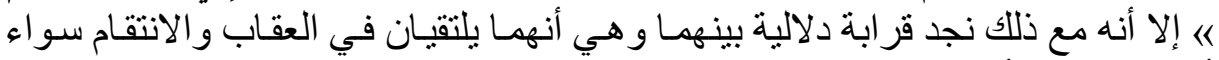

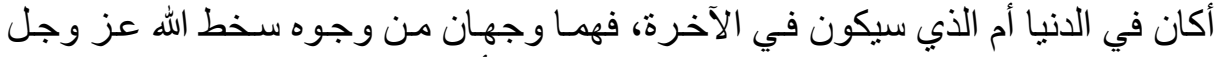

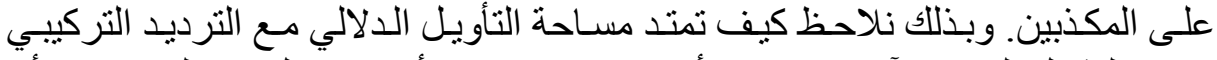

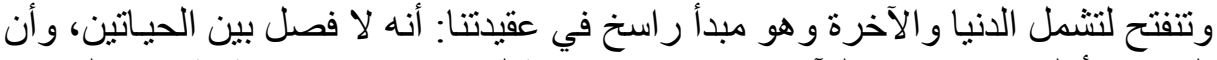

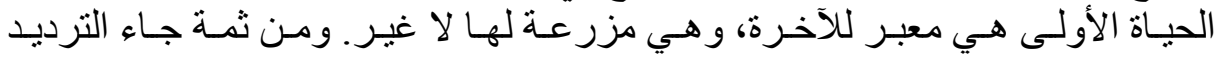

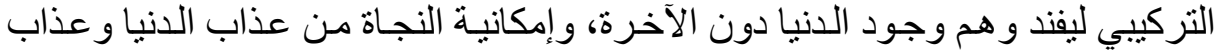
الآخرة، وليفيد بذلك استمر ارية عذاب المكذبين.

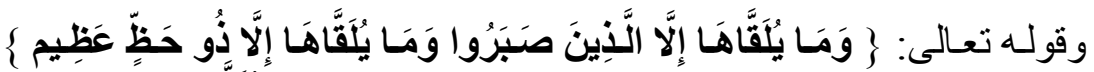

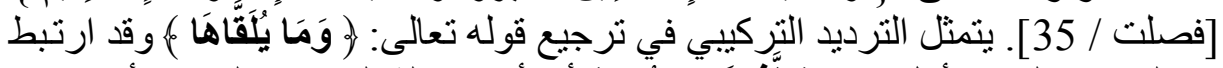

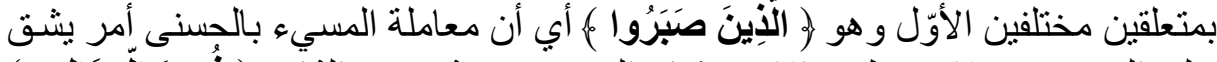

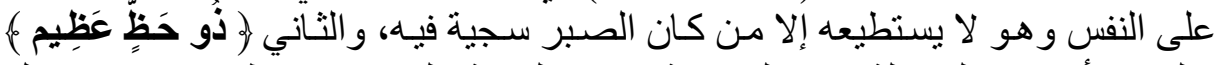

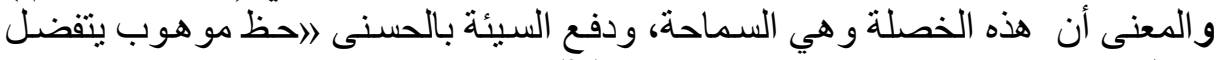

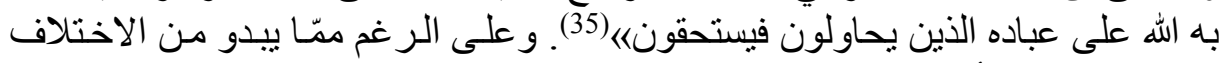

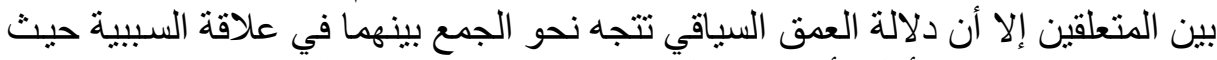

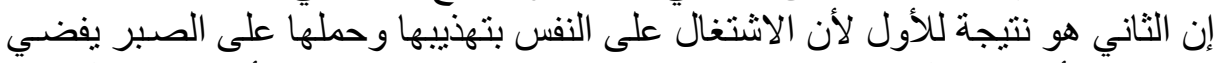

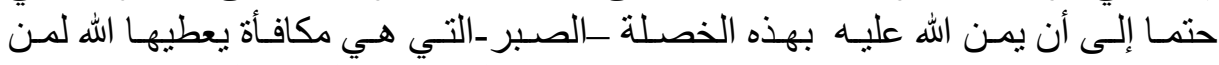

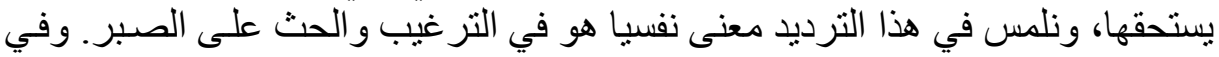




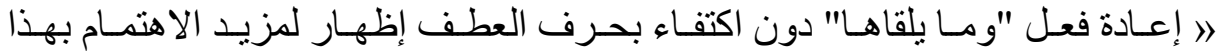

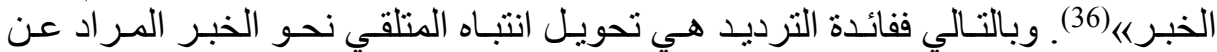
طريق الترجيع الصوتي الذي يكو ن سببا في تمكينه في النفس أكثر.

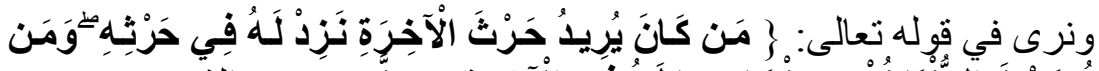

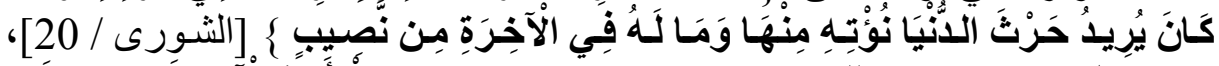

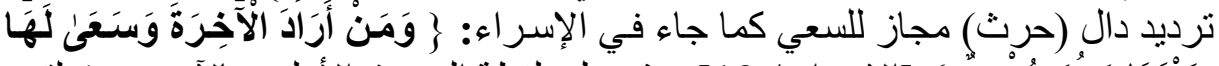

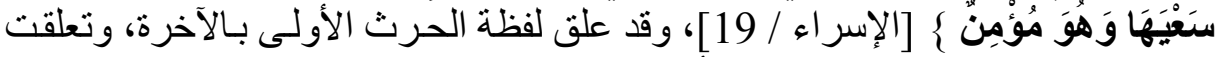

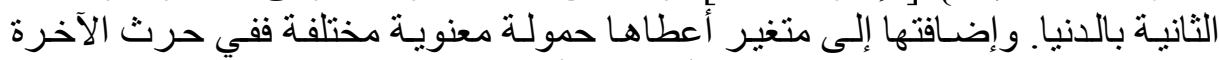

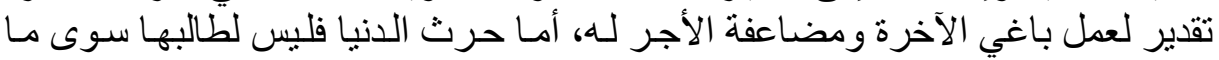

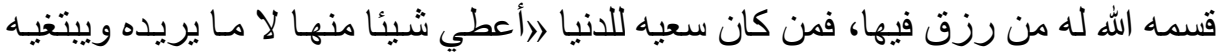

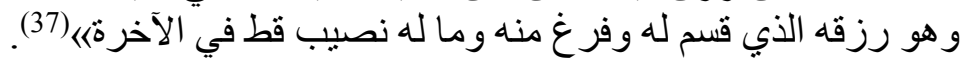

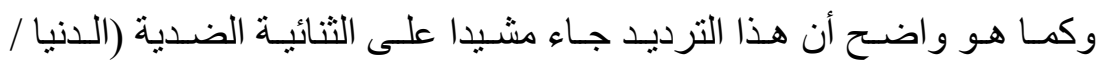

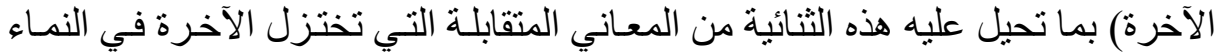

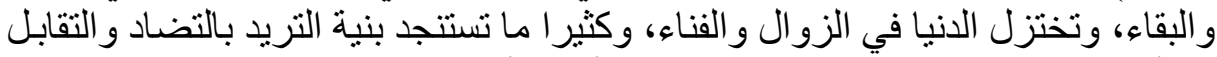

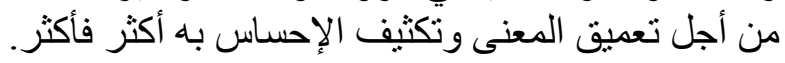

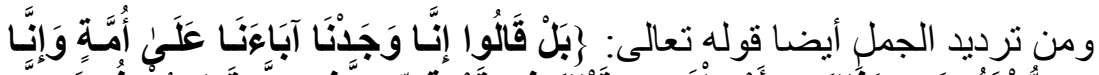

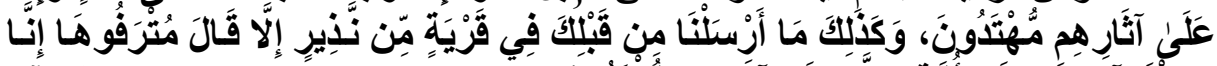

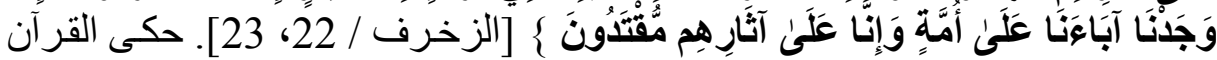

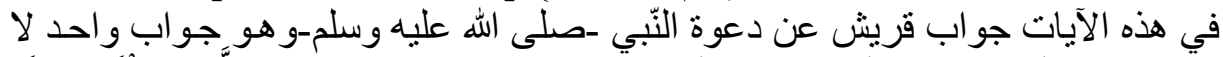

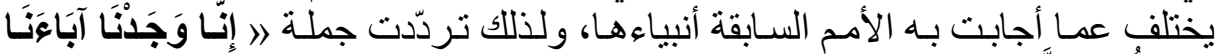

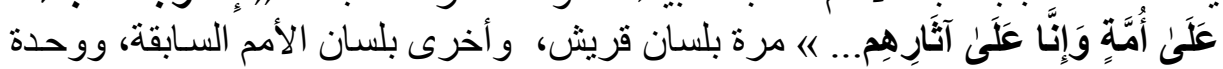

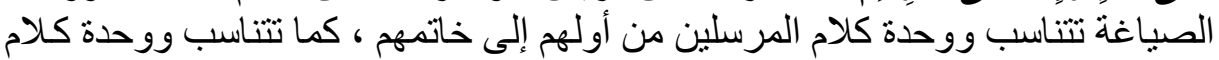

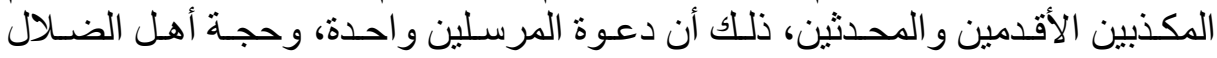

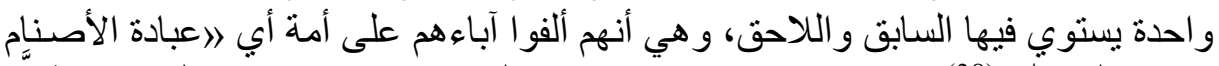

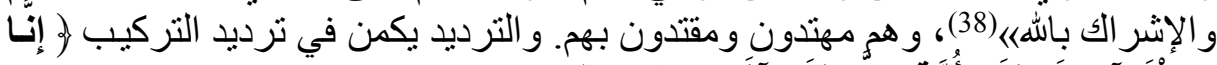

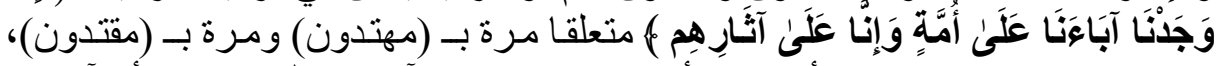

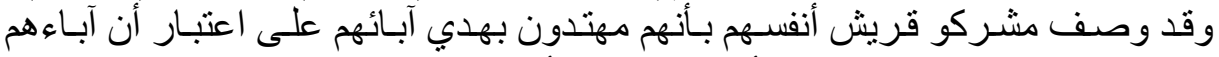

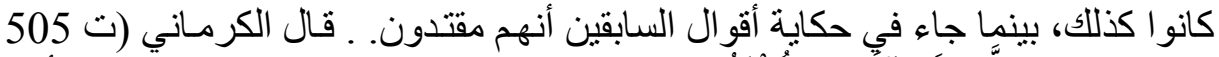

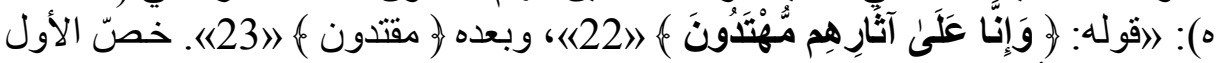

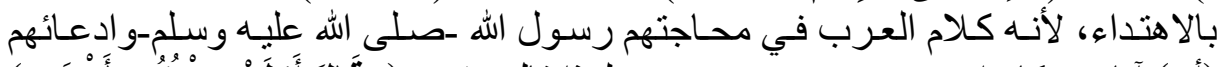

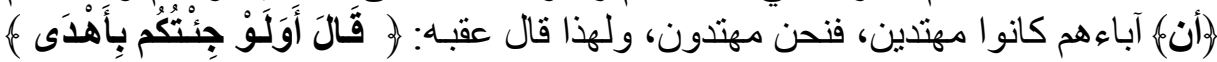

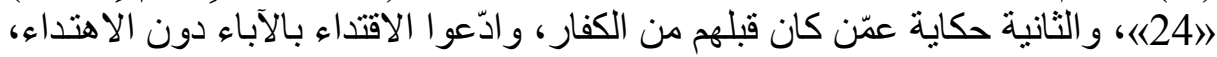

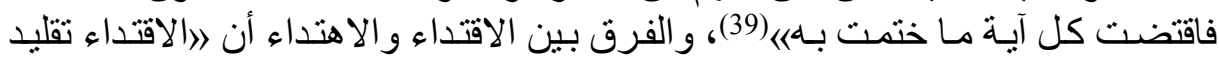

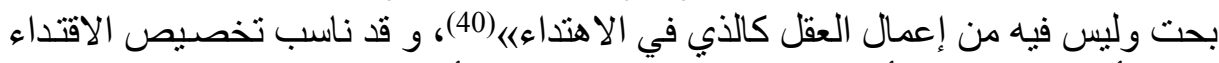

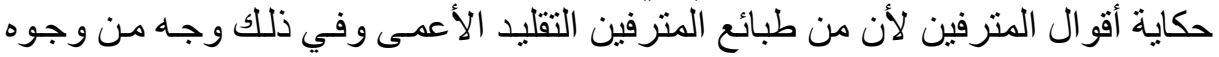
الإعجاز القر آني التي تكمن في رعنية لإنية المعاني(41).

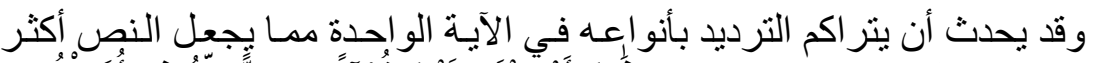

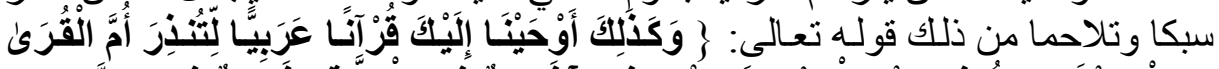

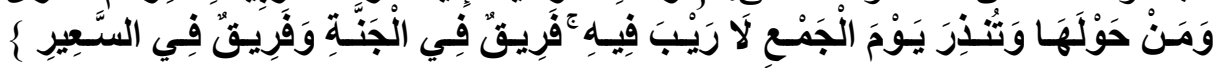


[الثورى / 07]، فالترديد يكمن في إعادة الفعل (تنذر) بدلالته لكن بفارق دلالي جزئي التي التئي سببه تعلقه في الأول بـ (أم القرى /مكة) وفي الثاني بـ (يوم الجمع/الفي القيامة).

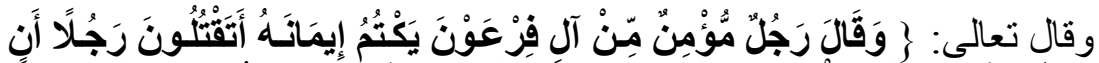

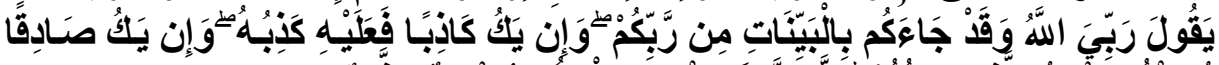

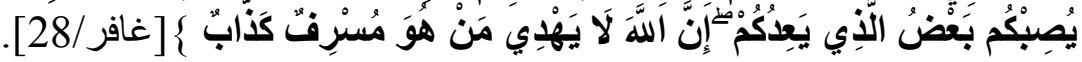
نجد بداية ترديد فعل القول الذي جاء مرة مسندا إلى مؤمن فرعون.

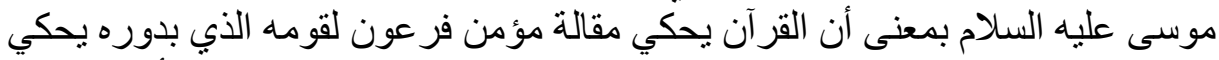

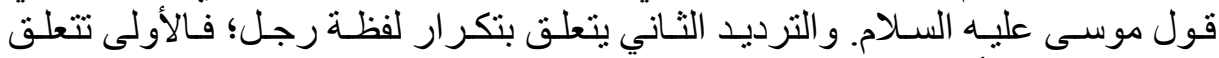

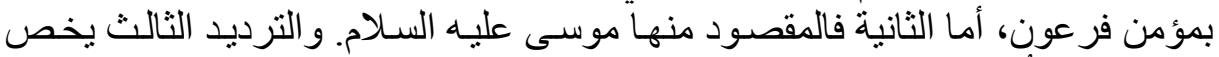

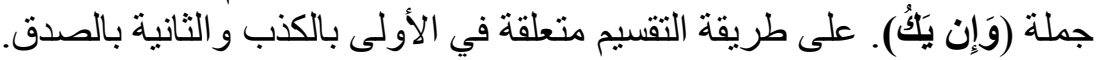

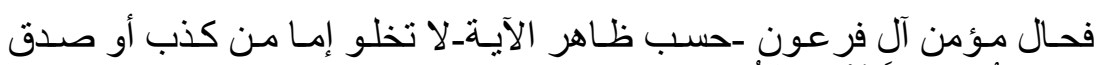

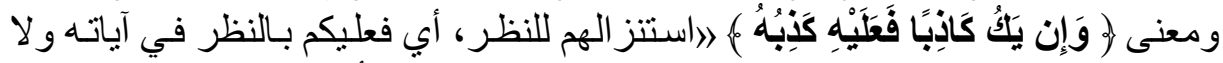

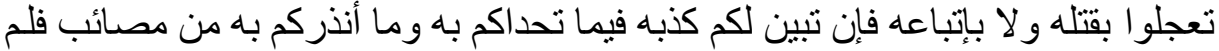

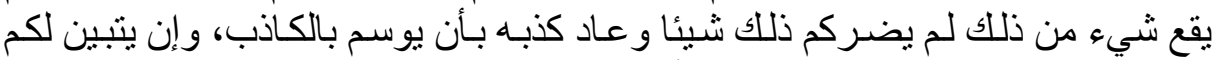

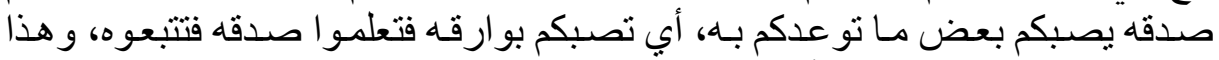

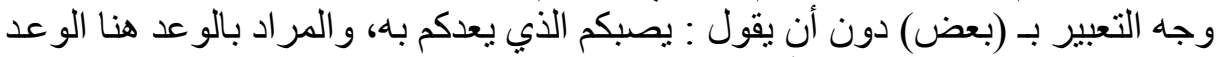

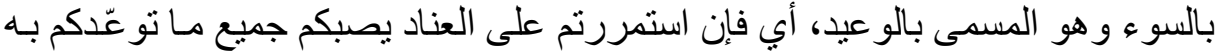
بطريق أولى《(42).

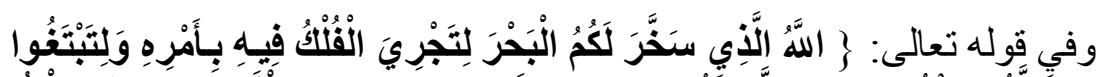

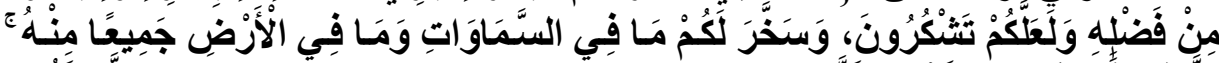

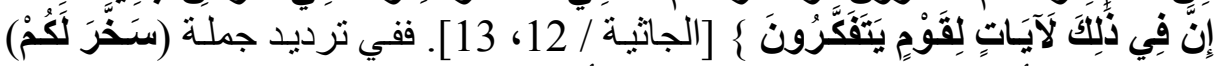

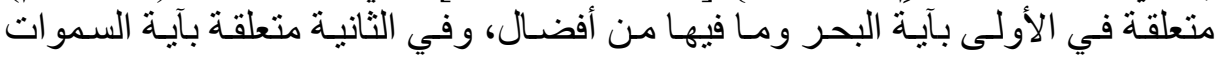

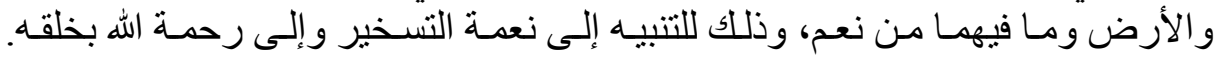

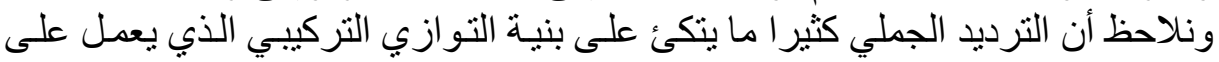

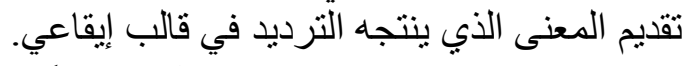

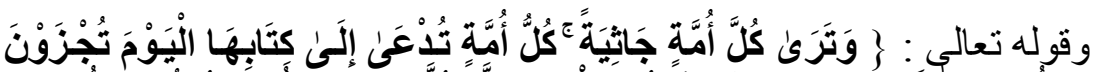

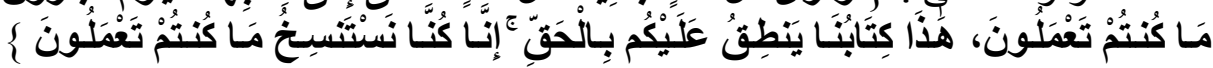

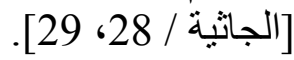

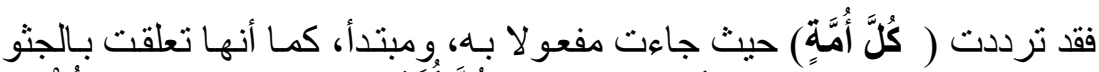

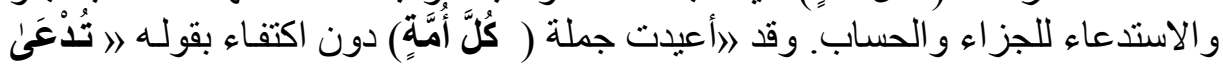

أو يدعون للتهويل و الدعاء إلى الكتاب بالأمم تجثو ، ثم تدعى كل أمة إلى كتابها

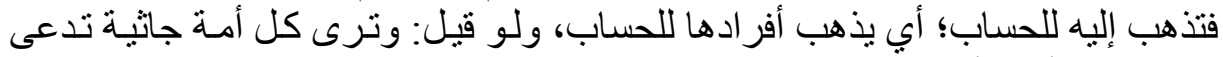

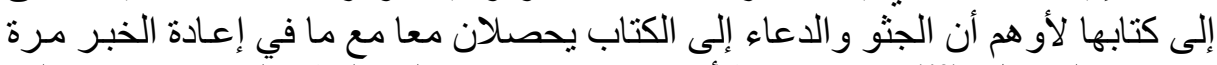

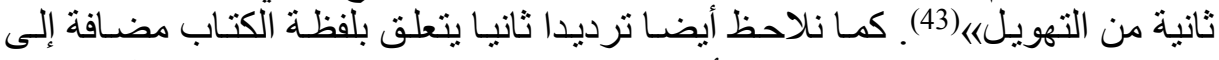

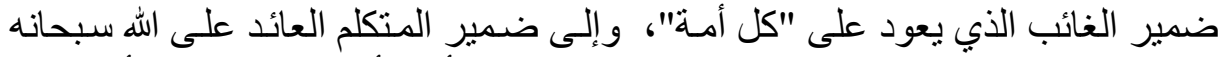

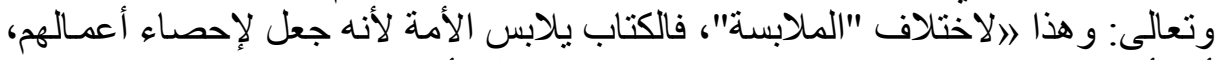

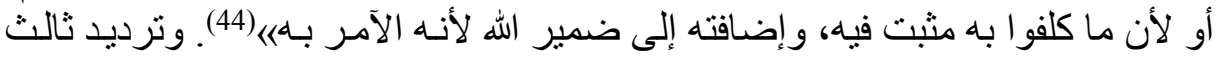

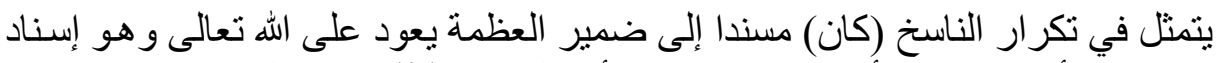

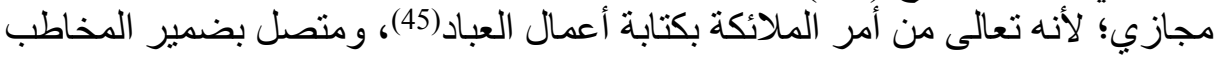

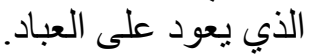


من هذه الآيات و غير ها نجد أن الترديد الجملي يجعل النص أكثر كثافة، وأكثر

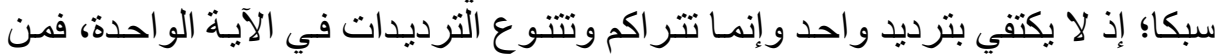
ترديد الكلمة إلى ترديد الجملة.

3.2-الترديد الحرفي أو العددي:

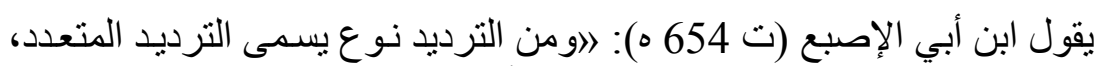

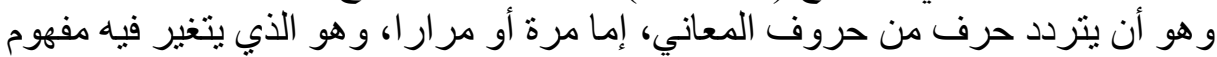

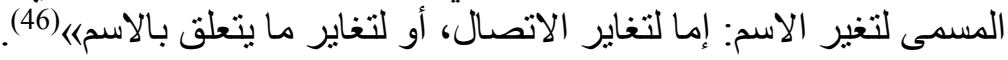

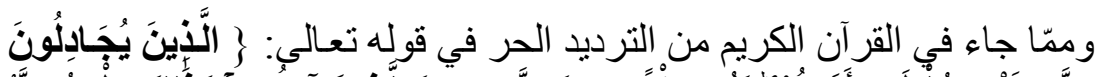

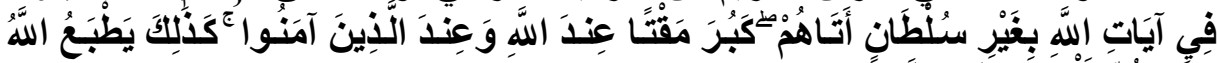

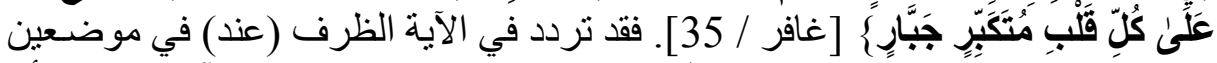

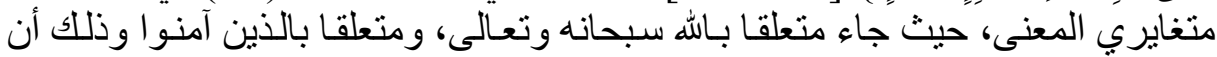

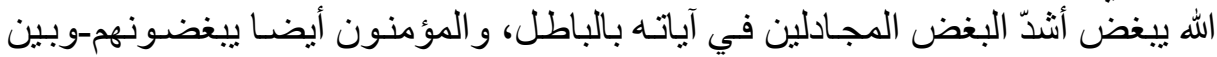

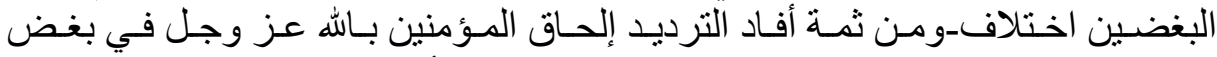

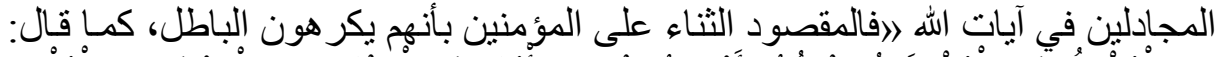

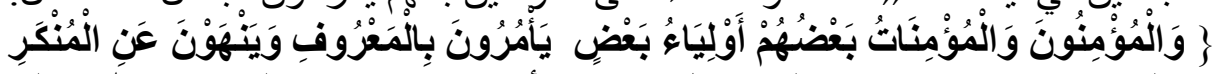

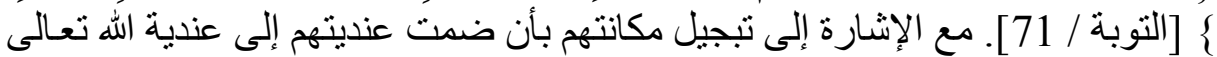
فعند ظرف مكان تستعمل في قرب التشريفي (47).

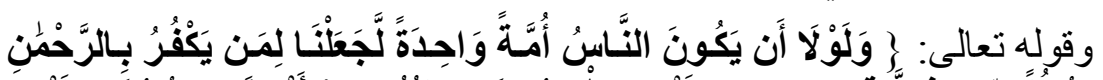

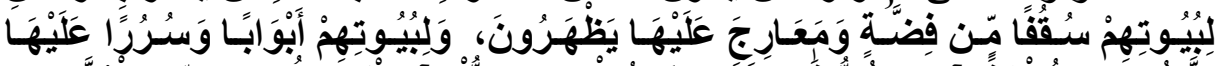

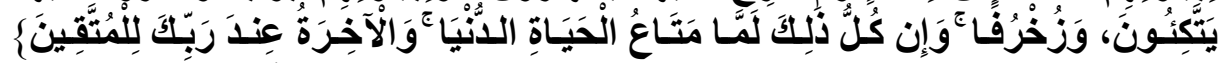

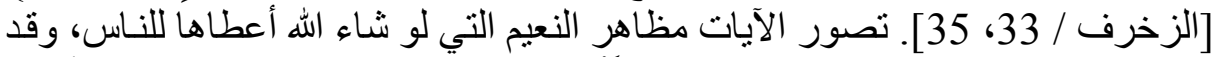

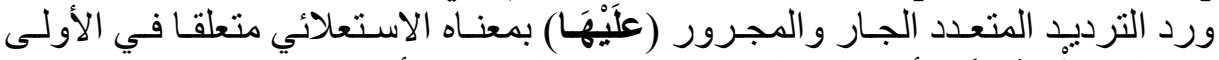

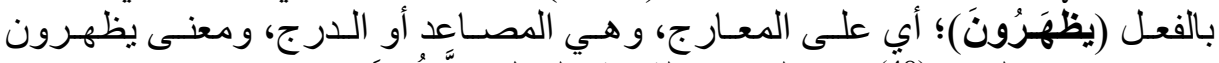

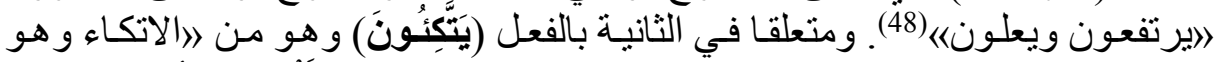

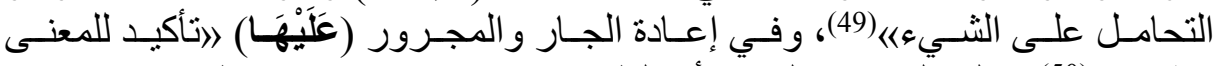

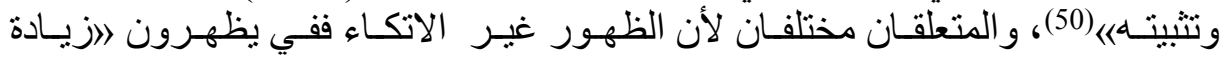

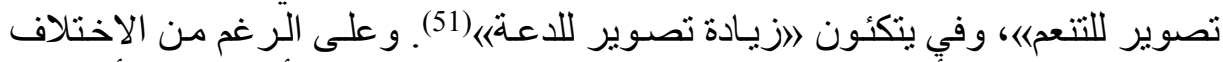

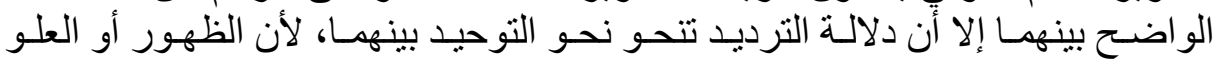

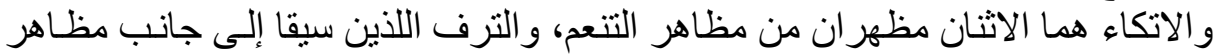

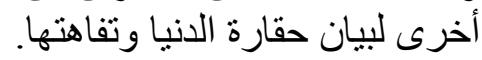

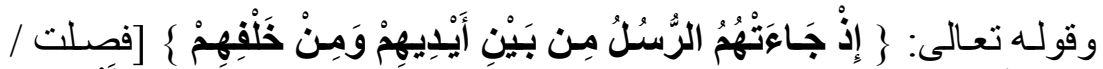

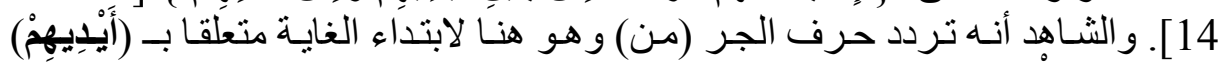

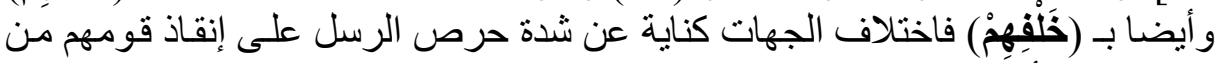

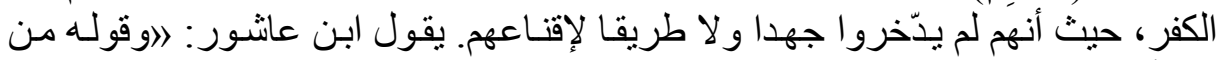

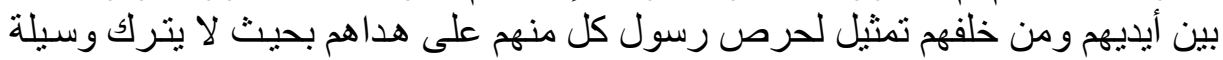

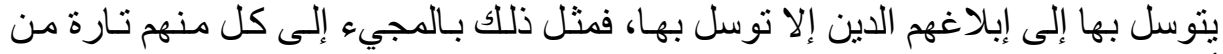
أمامه، وتارة من خلفه لا يترك له اله جهة|ر(52).

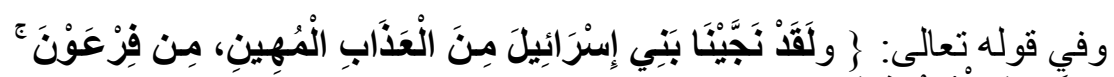

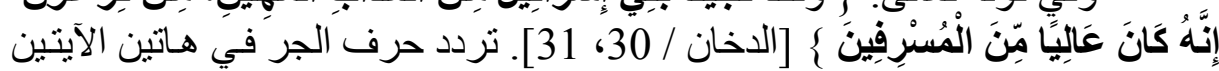

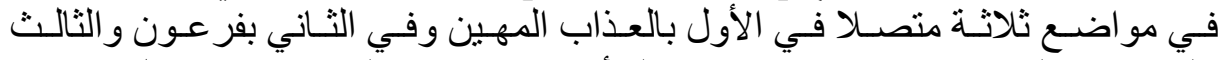

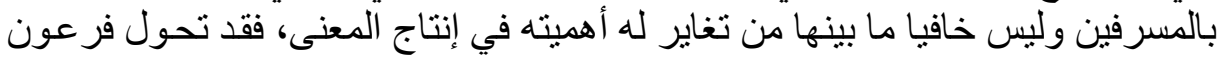


بفعل الترديد من المتسبب في عذاب بني إسر ائيل إلى أن يكون هو العذاب المهين ذاته،

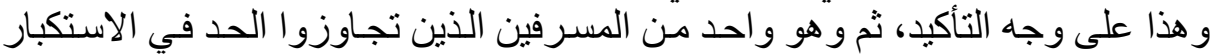

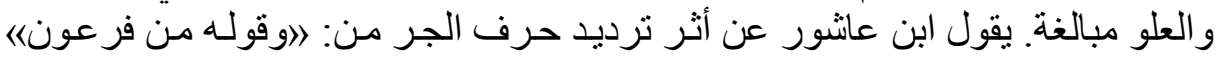

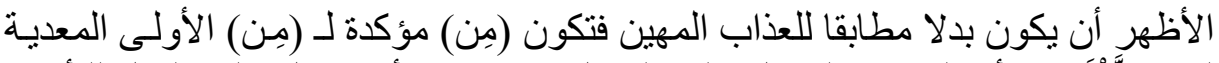

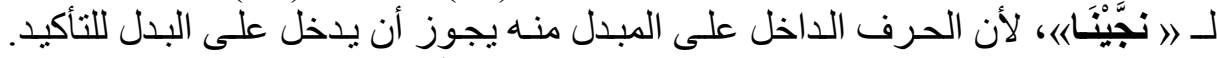

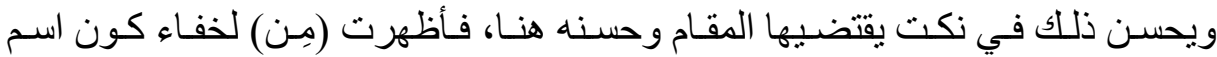

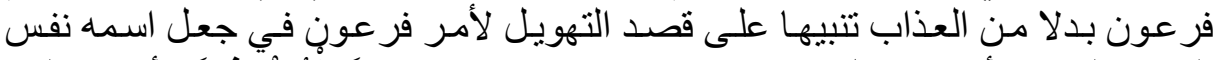

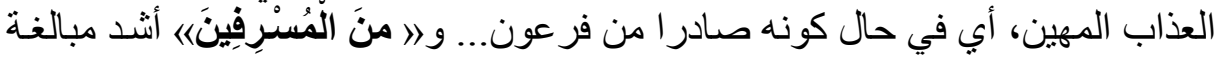

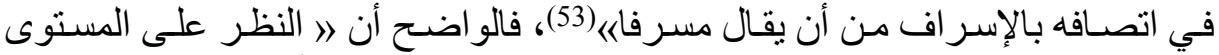

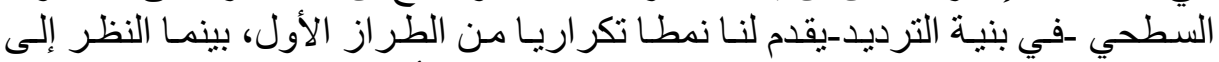

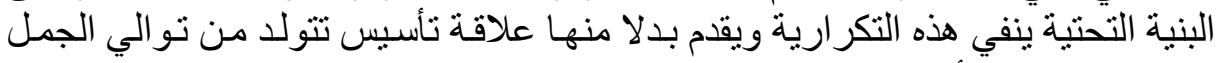
في شكل مجدول، أو في شكل سلسلة تتر ابط حلقاتها تر ابطا محكماء (54). ويقول تعالى: $\}$

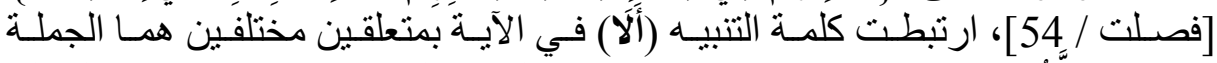

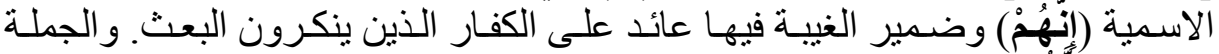

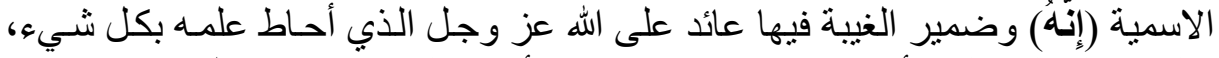

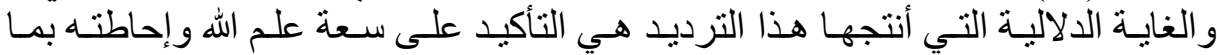
يقولون ويفعلون، ولاً يخفى ما يحمله هذا الخطّاب من التهديد و الو عيد.

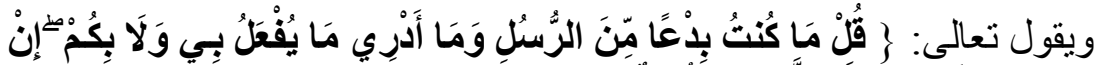

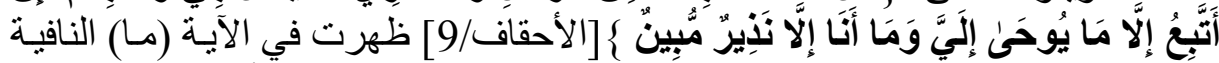

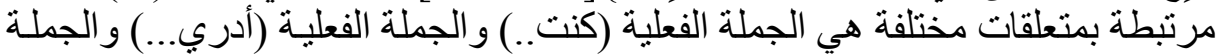

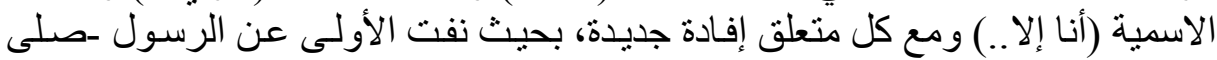

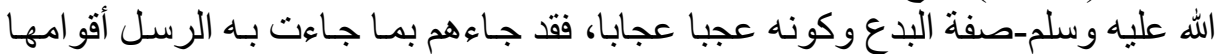

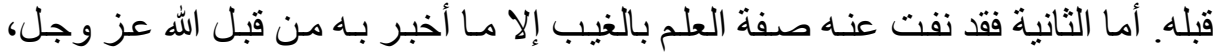

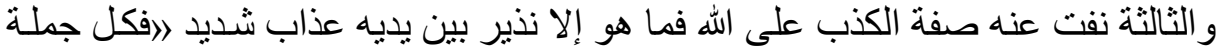

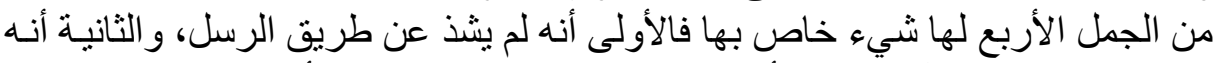

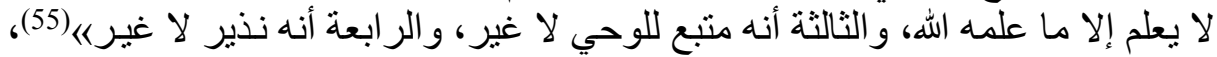

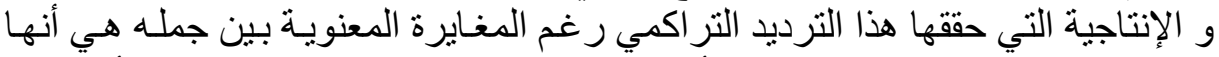

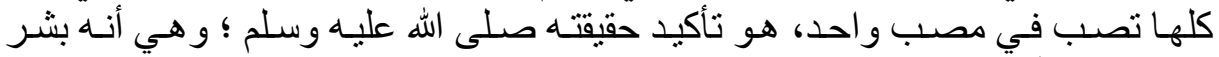

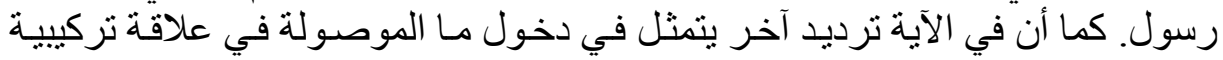

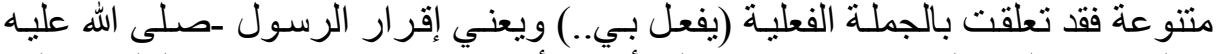

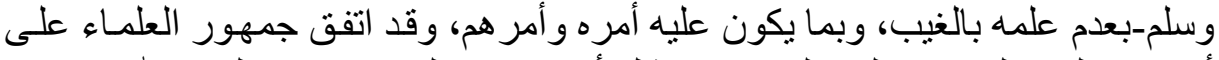

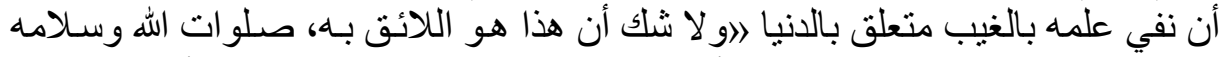

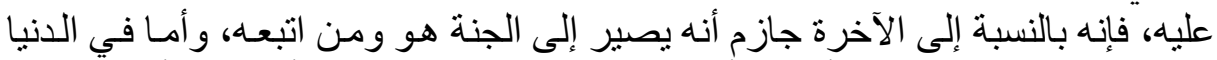

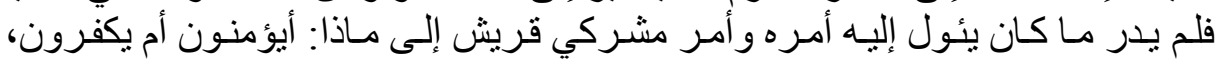

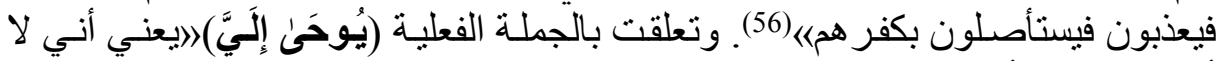

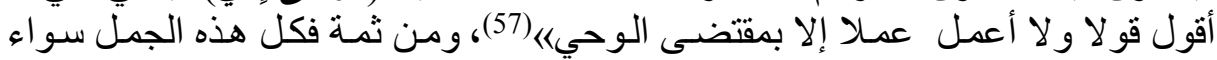

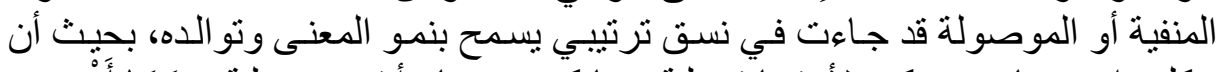

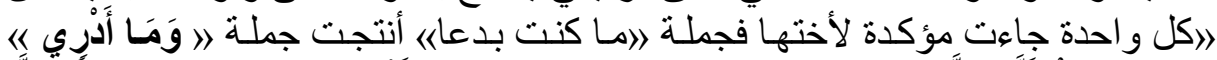

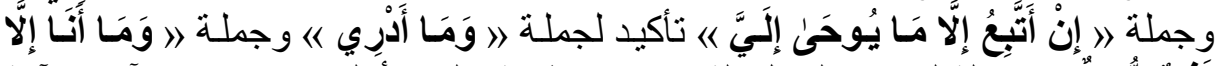

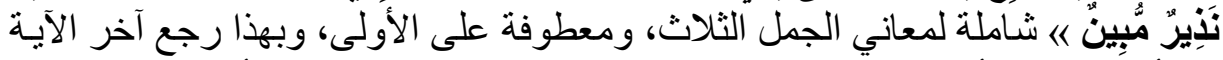

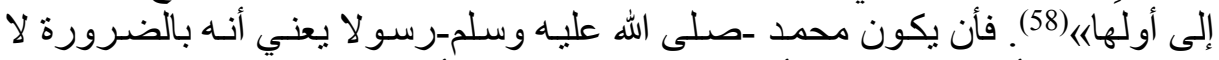

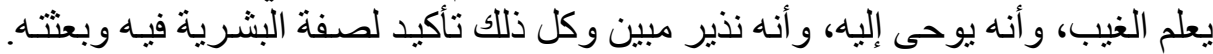

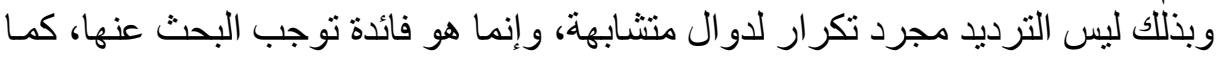




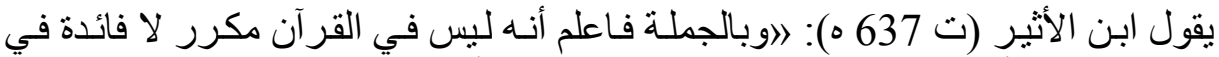

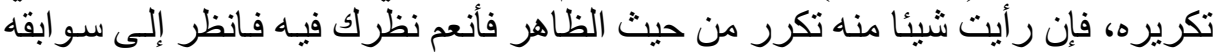

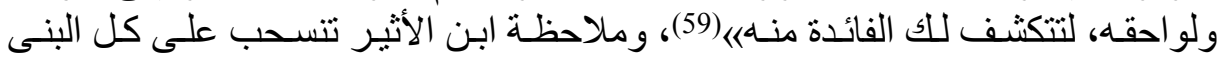

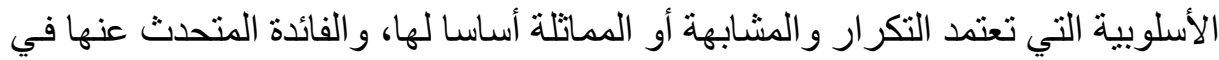
قوله هي فائض الدلالة التي ينتجها الترديد.

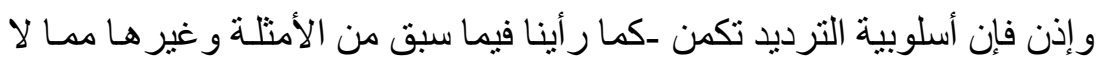

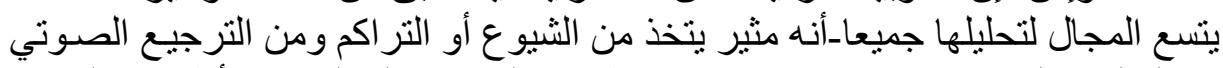

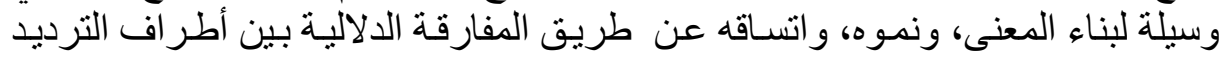

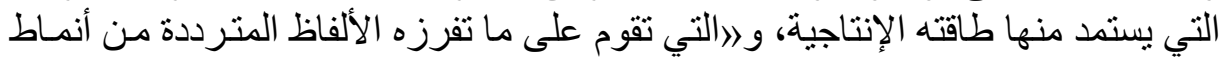

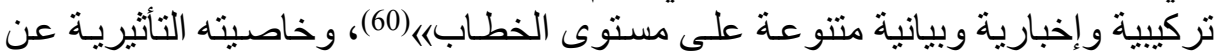

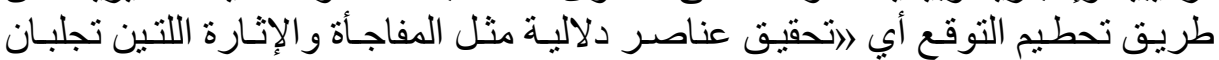
اهتمام السامع وتحقى سيّاق التوقع لديهای(61).

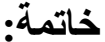

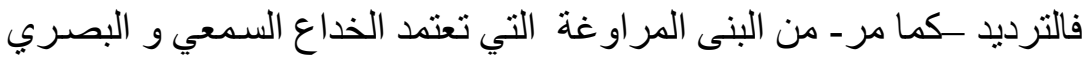

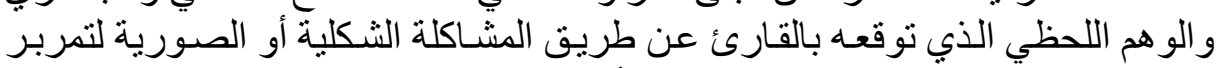

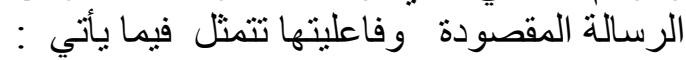

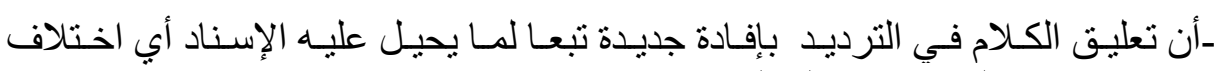
الإسناد، يؤدي إلى اختلاف الدالالة.

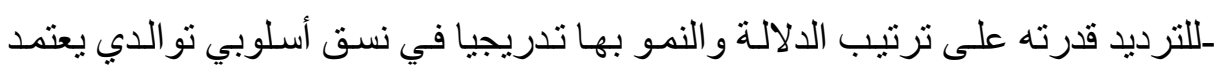
التكر ار اللفظي.

ـقررة الترديد على تغيير دلالة الكلام فمثلا من الترغيب إلى التر هيب كما رأينا .

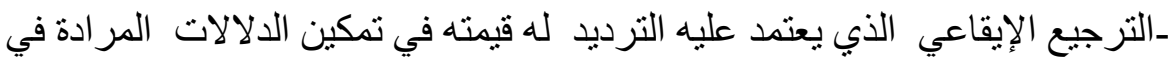
النفس عن طريق مخالفة التوقع و إحداث المفاجأة.

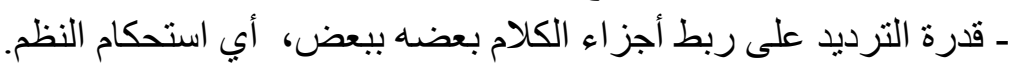

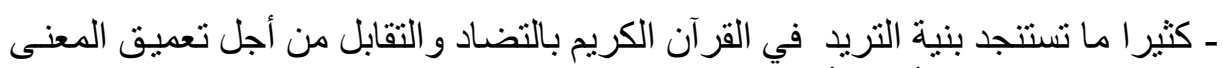
وتكثيف الإحساس با أكثر فأكثر.

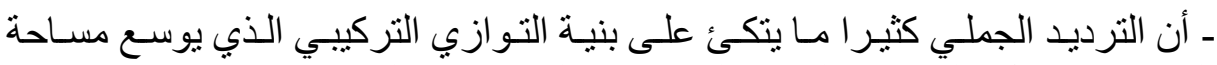

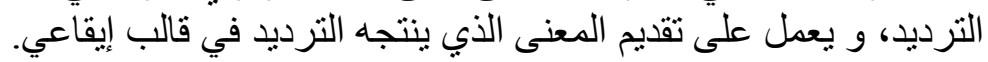

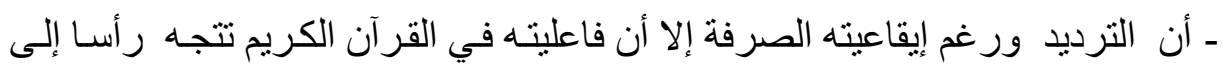

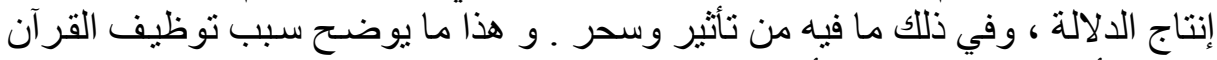

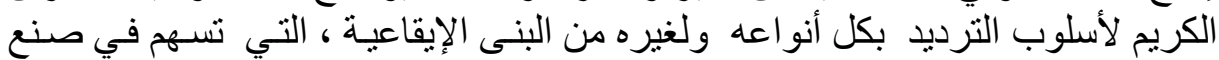
المعجزة الصوتية القرآنية. 


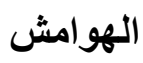

(1) ابن رشيق، أبو علي الحسن: العمدة في محاسن الثعر، المكتبة العصرية ، بيروت ،دط،

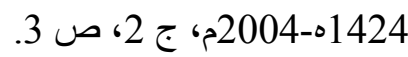

(2) الطر ابلسي، محمد الهادي: خصائص الأسلوب في الثوقيات، منشور ات الجامعة التونسية،

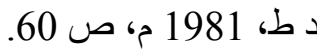
(3) الطر ابلسي، محمد الهادي: النص الأدبي وقضاياه عند ميشال ريفاتير من خلال كتابه 》(صناعة النص《) وجون كو هين من خلال كتابه 》الكلام السامي/ي، مجلة فصول، مجلة النقد

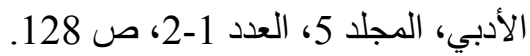

(4) عبد المطلب، محمد: البلاغة العربية قراءة أخرى، مكتبة لبنان ناشرون ،ط1 ، 128 1997، ص

(5) ينظر : جون كو هين: النظرية الثعرية بناء لغة الشعر، اللغة العليا، نرجمة: أحمد درويش، دار غريب ، القاهرة دط، 2000، ص صن 457-458. (6) الطرابلسي، محمد الهادي: النص الأدبي وقضاياه عند ميشال ريفاتير من خلال كتابه

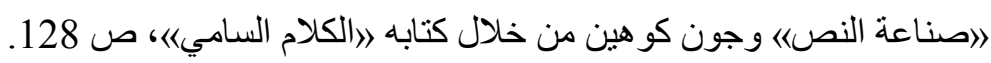

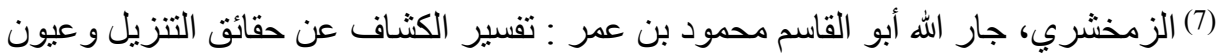

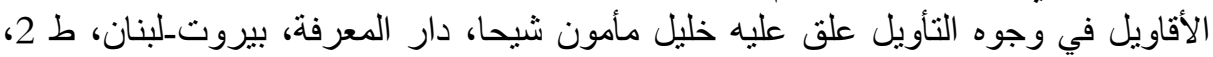

$$
\begin{aligned}
& \text { (1426ه - } 2005 \text { م)، ج 24، ص صد } 952 . \\
& \text { (8) المصدر السابق، ج 24، ص صل } 952 .
\end{aligned}
$$

(9)الطبري، أبو جعفر محمد بن جرير: جامع البيان عن تأويل آي القرآن، تحقيق: عبد الله بن

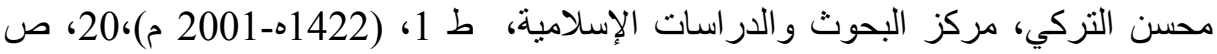

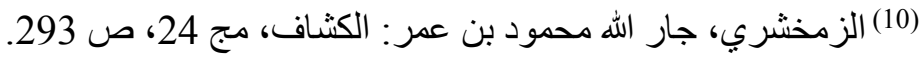

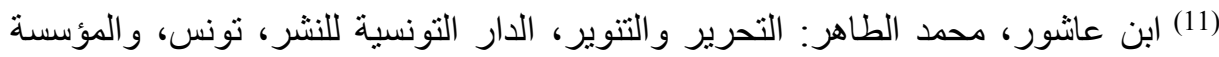

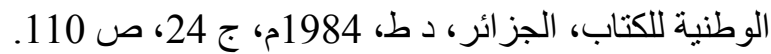

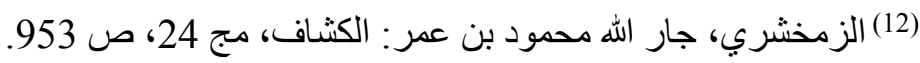

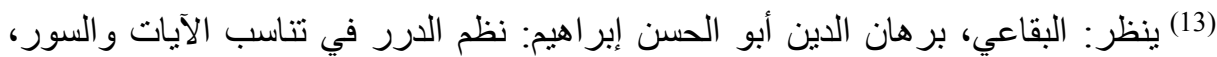

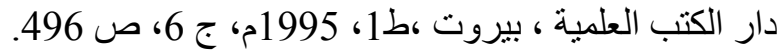

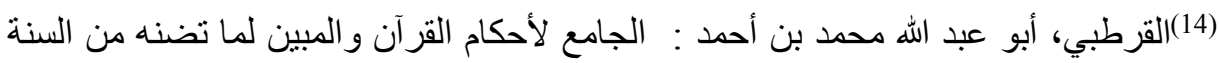

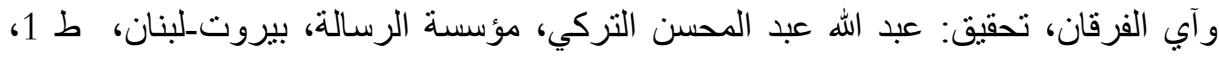

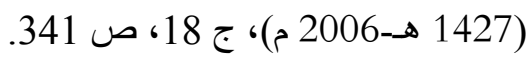

15) ينظر: عياشي، منذر:- مقالات في الأسلوبية، منشورات اتحاد الكتاب العرب، دمشق، ط

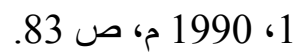

(16) عبد المطلب، محمد: البلاغة والأسلوبية، مكتبة لبنان ناشرون ، بيروت - لبنان ، ط1 ،

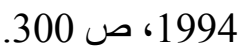

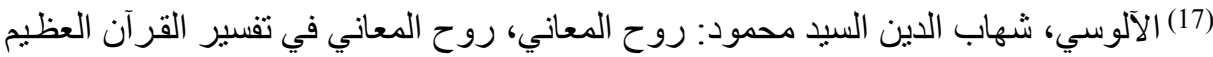

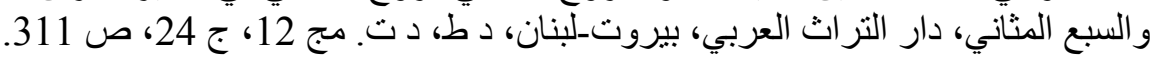
(18) ينظر: عز الدين علي السيد: التكرير بين المثير والتأثير، عالم الكتب، بيروت، ط 1ا، 12 
(19) البقاعي، برهان الدين أبو الحسن إبراهيم: نظم الدرر في تناسب الآيات و السور ، ج 6، ص

(20) الزمخشري، جار الله محمود بن عمر : الكثاف، ج 2427، ص صد 967.

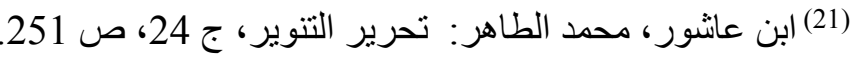

(22) الطرابلسي، محمد الهادي: النص الأدبي وقضاياه عند ميثال ريفاتير من خلال كتابه

》(صناعة النص《) وجون كو هين من خلال كتابه 》الكلام السامي《)، ص 128.

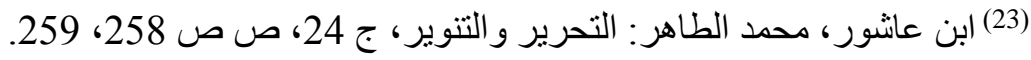

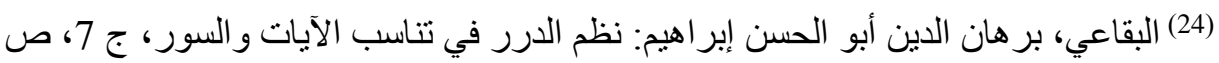

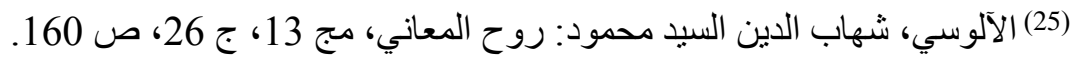

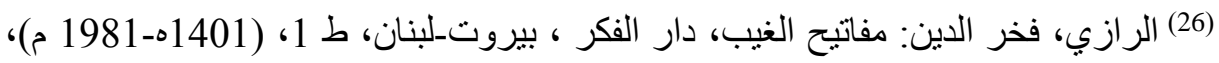

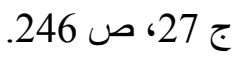

(27) أبو موسى، محمد: آل حم الثورى_الزخرف_الدخان، دراسة في أسرار البيان، مكتبة

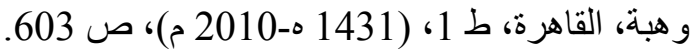

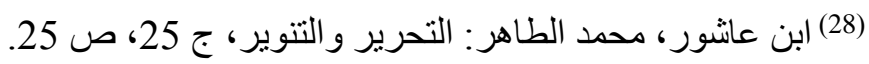

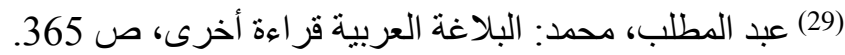

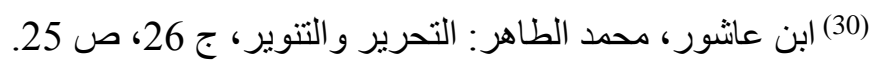

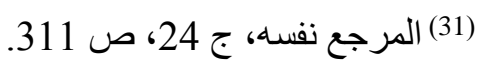

(32) ينظر : المرجع نفسه، الصفحة نفسها.

(33) عبد المطلب، محمد: بناء الأسلوب في شعر الحداثة التكوين البديعي، دار المعارف،

القاهرة، ط 1، 1993 م ، ص ص 404.

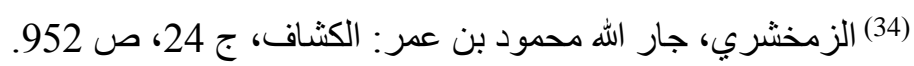

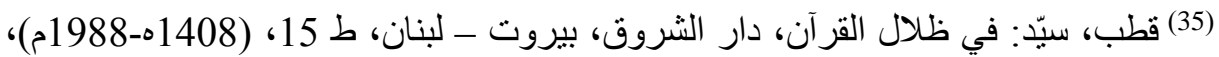

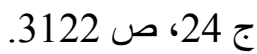

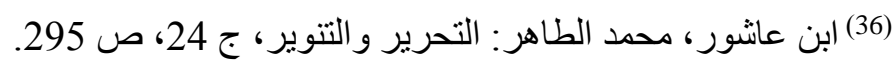

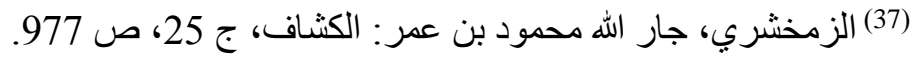

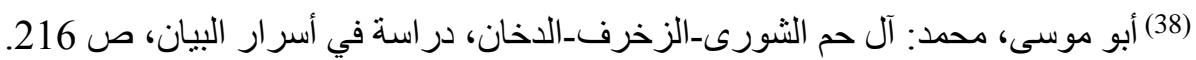

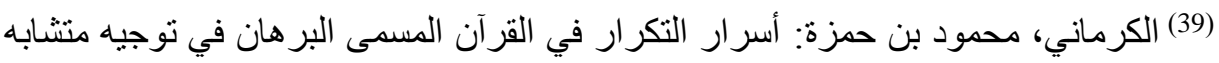

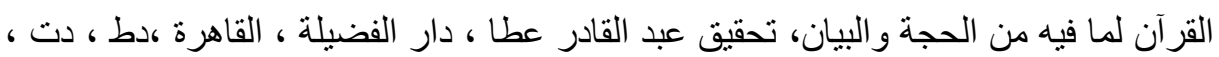

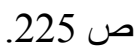

(40) أبو موسى، محمد: آل حم الثورى_الزخرف_الدخان، دراسة في أسرار البيان، ص 216.

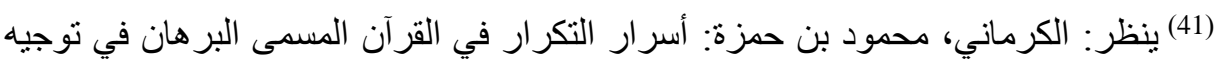
متشابه القرآن لما فيه من الحجة والبيان، هامش صد صن 225.

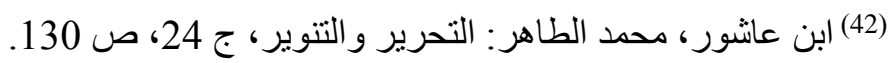

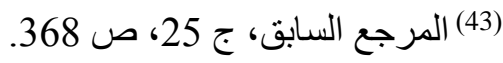


(44) المرجع نفسه ، الصفحة نفسها.

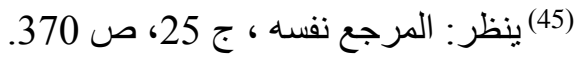

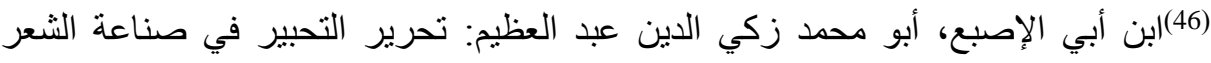

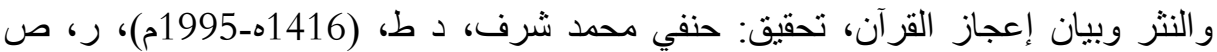

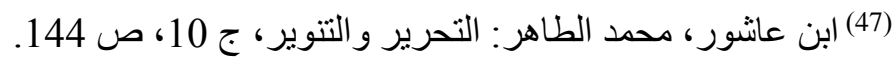

(48) الواحدي، أبو الحسن علي بن أحمد: الوسيط في تفسير القرآن المجيد، تحقيق: عادل أحمد ألمدي

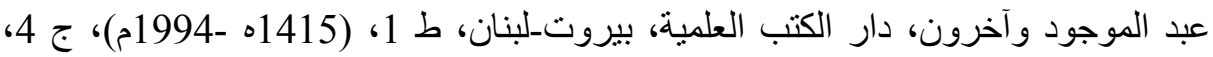

$$
\text { (49) المصدر السابق، ج 4، ص (50) } 71 .
$$

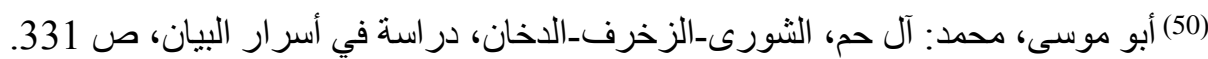

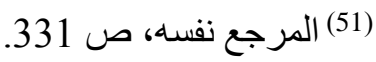

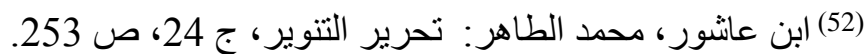

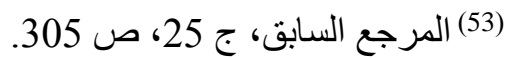

(54) عبد المطلب، محمد: بناء الأسلوب في شعر الحداثة، التكوين البديعي، ص 390.

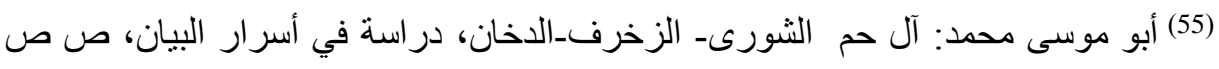
.366-356 (56) ابن كثير، أبو الفداء عماد الدين بن إسماعيل:تفسير القرآن العظيم، دار الدعوة الإسلامية

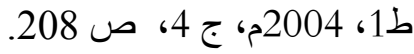

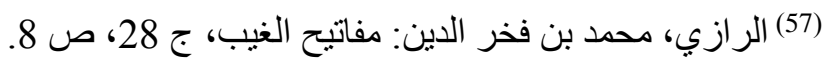

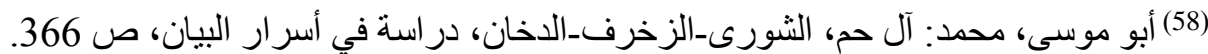

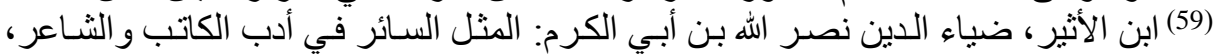

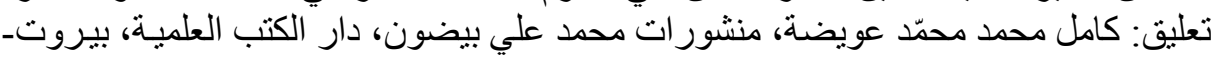

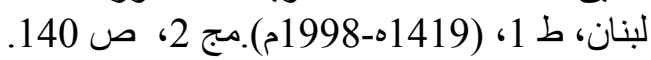
(60) جاب الله، أسامة عبد العزيز: جماليات التلوين الصوتي في القرآن الكريم، عالم الكتب

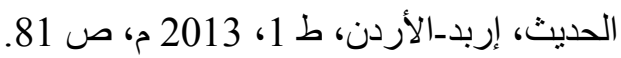

(61) المرجع نفسه، الصفحة نفسها. 
قائمة المصادر والمراجع

القر آن الكريم برواية حفص - إنص

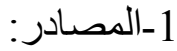

1-ابن الأثير، ضياء الدين نصر الله بن أبي الكرم: المثل السائر في أدب الكاتب

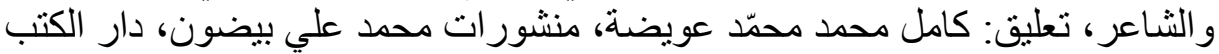

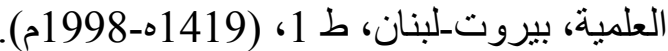

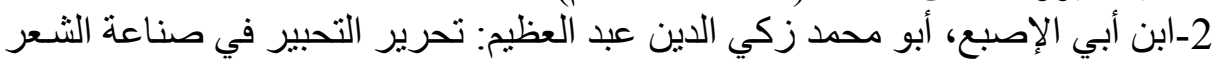

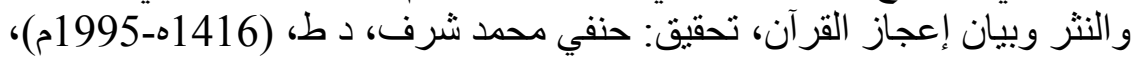

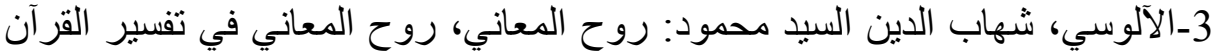

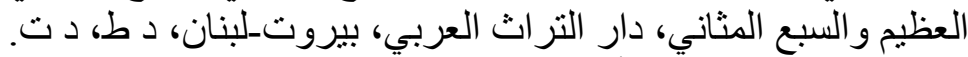

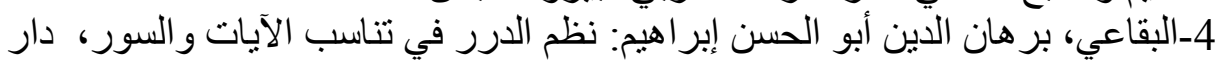

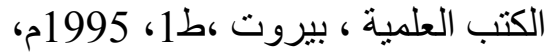
5- ابن رشيق، أبو علي الحسن: العددة في محاسن الشعر ، تحقيق محمد محي الدين عبد

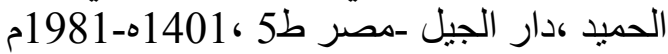

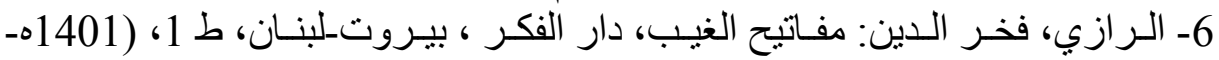

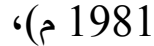

7ـالزمخشري، جار الله أبو القاسم محمود بن عمر : تفسير الكثـاف عن حقائق التنزيل

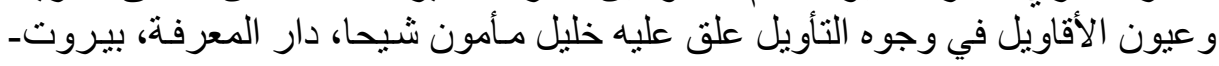

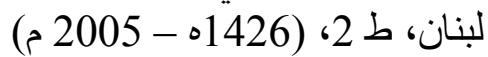

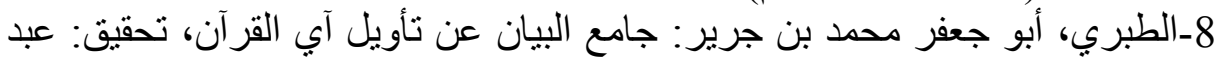

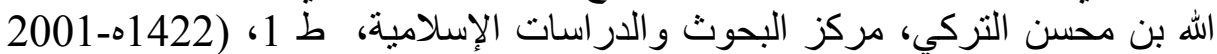

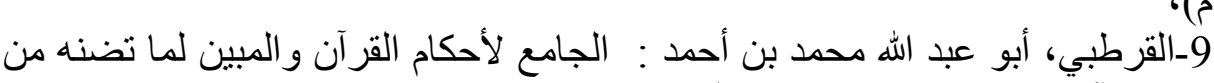
السنة وآي الفرقان، تحقيق: عبد الله عبد المحسن التركي، مؤسسة الرسالة، بيروتـ

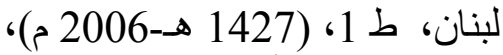
10-ابن كثير، أبو الفداء عماد الدين بن إسماعيل:تفسير القرآن العظيم، دار الدعوة

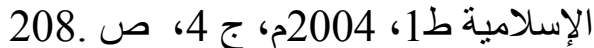
11-الكرماني، محمود بن حمزة: أسرار التكرار في القرآن آن المسمى البر هان في توجيه متشابه القر آن لما فيه من الحجة والبيان، تحقيق عبد القادر عطا ، دار الفضيلة ، القاهرة التران

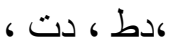
12-الواحدي، أبو الحسن علي بن أحمد: الوسيط في تفسير القرآن المجيد، تحقيق: عادل

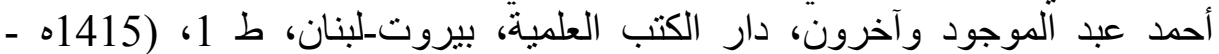

1- أبو موسى، محمد: آل حم الثورى-الزخرفـالدخان، در اسة في أسرار البيان، مكتبة

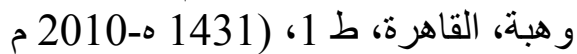

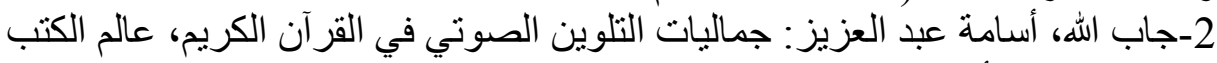

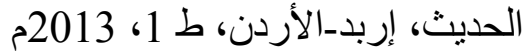
3-جون كوهين: النظرية الشعرية بناء لغة الثُعر، اللغة العليا، ترجمة: أحمد درويش، دار غريب ، القاهرة دط، 2000 200ن 4-الطرابلسي، محمد الهادي: خصائص الأسلوب في الشوقيات، منشورات الجامعة

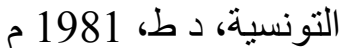
5-ابن عاثور، دحمد الطاهر: التحرير والتنوير، الدار التونسية للنشر، تونس، 


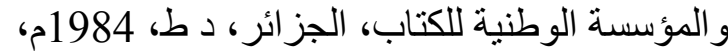

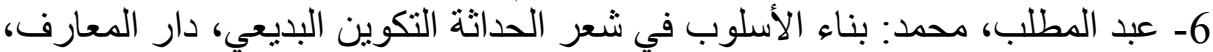

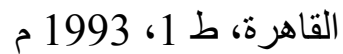

7- عبد المطلب، محمد: البلاغة و الأسلوبية، مكتبة لبنان نانشرون ، بيروت - لبنان ،

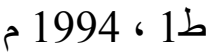

8- عبد المطلب، محمد: البلاغة العربية قراءة أخرى، مكتبة لبنان ناشرون ،ط1 ، 1997

9-عياشي، منذر:- مقالات في الأسلوبية، منشورات اتحاد الكتاب العرب، دمشث، ط 1، 1990 من 190 10-قطب، سيّد: في ظلال القرآن، دار الثروق، بيروت - لبنان، ط 15، (1408هـ ، (1988 3-المجلات الطر ابلسي، محمد الهادي: النص الأدبي وقضاياه عند ميشال ريفاتير من خلال كتابه

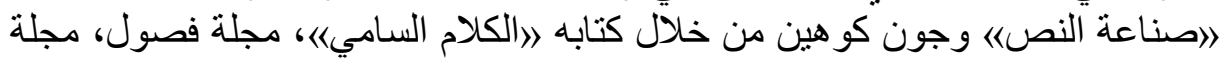

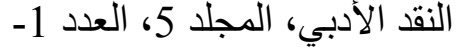

